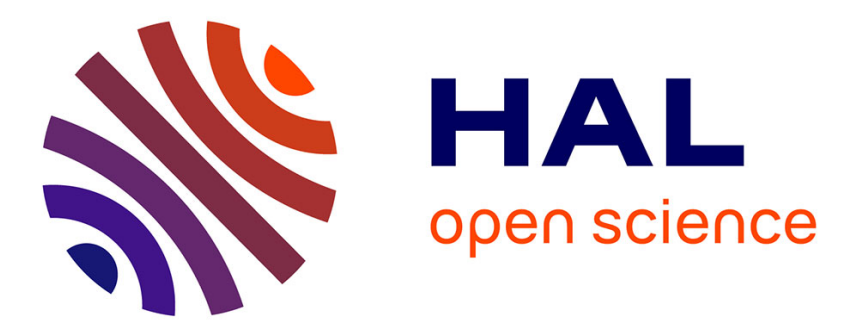

\title{
Osmium isotope constraints on formation and refertilization of the non-cratonic continental mantle lithosphere
}

Laurie Reisberg

\section{- To cite this version:}

Laurie Reisberg. Osmium isotope constraints on formation and refertilization of the non-cratonic continental mantle lithosphere. Chemical Geology, 2021, 574, pp.120245. 10.1016/j.chemgeo.2021.120245 . hal-03325836

\section{HAL Id: hal-03325836 \\ https://hal.univ-lorraine.fr/hal-03325836}

Submitted on 25 Aug 2021

HAL is a multi-disciplinary open access archive for the deposit and dissemination of scientific research documents, whether they are published or not. The documents may come from teaching and research institutions in France or abroad, or from public or private research centers.
L'archive ouverte pluridisciplinaire HAL, est destinée au dépôt et à la diffusion de documents scientifiques de niveau recherche, publiés ou non, émanant des établissements d'enseignement et de recherche français ou étrangers, des laboratoires publics ou privés. 
Osmium isotope constraints on formation and refertilization of the non-cratonic continental mantle lithosphere

Laurie Reisberg

Centre de Recherches Pétrographiques et Géochimiques

UMR 7358 CNRS - Université de Lorraine

laurie.reisberg@univ-lorraine.fr 


\section{Highlights}

- Correlations between Os isotopes and fertility indices in non-cratonic peridotites

- Such correlations inconsistent with recent refertilization of ancient harzburgites

- Can be explained by ancient refertilization followed by radiogenic ingrowth

- Suggests harzburgite depletion causally related to subsequent refertilization

- Whole rock correlations and internal Os isotope heterogeneity are not inconsistent 


\begin{abstract}
It is increasingly accepted that many lherzolites in the lithospheric mantle formed by refertilization of depleted harzburgites, rather than by small degrees of melt extraction from fertile precursors. Such refertilization is often assumed to be linked to tectonic events unrelated to and much younger than the original partial melting episodes that left the depleted harzburgitic residues. Osmium isotopes provide a means of testing this assumption. Data for ${ }^{187} \mathrm{Os} /{ }^{188}$ Os are now available from more than 50 studies of peridotites from the non-cratonic lithospheric mantle, including both xenoliths in alkali basalts and mantle tectonites of subcontinental affinity. The results from these studies confirm the long-recognized observation that whole rock Os isotope compositions are frequently correlated with indices of peridotite fertility such as $\mathrm{Al}_{2} \mathrm{O}_{3}$ content, with $>50 \%$ of the samples having ${ }^{187} \mathrm{Os} /{ }^{188} \mathrm{Os}$ ratios plotting within $\pm 1.5 \%$ of correlation lines between the estimated Primitive Upper Mantle (PUM) composition and the least radiogenic sample in each suite. A simple melt percolation model was developed that shows that such trends cannot result from direct precipitation of exsolved radiogenic sulfides, because any Os initially present in the circulating magma would be trapped by sulfides at the very bottom of the column, due to the extreme chalcophility of this element. Refertilized peridotites higher in the column would thus have unradiogenic Os compositions. The absence of fertile lherzolites with unradiogenic Os isotope compositions, the expected products of percolation of young melts through ancient harzburgites, argues that this process is extremely rare. Instead, the addition of Re during melt percolation occuring soon after harzburgite depletion would produce correlations between $\mathrm{Re} / \mathrm{Os}$ and $\mathrm{Al}_{2} \mathrm{O}_{3}$ that with time would develop into correlations between ${ }^{187} \mathrm{Os} /{ }^{188} \mathrm{Os}$ and $\mathrm{Al}_{2} \mathrm{O}_{3}$ passing through the PUM composition. Such correlations would be linear, as observed, if $\mathrm{D}_{\operatorname{Re}}{ }^{\text {sulfsil }}{ }^{\text {is }} \sim 400$, the approximate value predicted for this parameter for FeO-rich magmas at $f \mathrm{O}_{2}$ and $f \mathrm{~S}_{2}$ values appropriate for non-arc mantle melting conditions. This perspective is fully consistent with the substantial variation in ${ }^{187} \mathrm{Os} /{ }^{188}$ Os ratios found among sulfides taken from individual hand samples, if radiogenic ingrowth over time is associated with extensive, but incomplete, diffusive reequilibration.
\end{abstract}

The conclusion that refertilization must follow soon after harzburgite formation has several implications. First, it suggests that the original melt depletion episodes are causally linked to the subsequent refertilization, which could result from percolation of the remaining melts through the cooling lithosphere. Second, early refertilization has consequences for the longterm stability of the lithosphere, since lherzolites are denser rocks than harzburgites. A final 
observation is that the systematic correlations between Os isotope compositions and fertility indices observed in most non-cratonic peridotite suites are unlikely to form in suprasubduction settings, where melts often carry ultramafic xenoliths with radiogenic and chaotic ${ }^{187} \mathrm{Os} /{ }^{188} \mathrm{Os}$ ratios. Instead, extensive melting above a mantle plume, followed soon after by refertilization with remaining melts as the plume cools, could explain the observed systematics. This newly formed mantle lithosphere could then be tectonically juxtaposed beneath continental crust formed above subduction zones.

Keywords: mantle lithosphere, osmium isotopes, refertilization, harzburgites, lherzolites

\section{Introduction}

The origin and evolution of the non-cratonic subcontinental lithospheric mantle (SCLM) underlying most of the Earth's continental mass remains poorly understood despite decades of study. This mantle domain, which is sampled by xenoliths in alkali basalts and by orogenic peridotite massifs, is composed predominantly of peridotites with compositions varying from depleted harzburgites to fertile lherzolites. For many years, this range of compositions was generally interpreted to result from varying degrees of melt extraction from a fertile lherzolite precursor. Nevertheless, possible inconsistencies in this scenario were soon recognized, notably the often-observed enrichment of incompatible elements in harzburgites (e.g. Frey and Prinz, 1978), which is inconsistent with simple melt extraction models. The development of melt percolation models (Navon and Stolper, 1987; Vernières et al.,1997) demonstrated how the geochemical composition of a peridotite column could be profoundly modified by the percolation of magmas out of equilibrium with the original peridotite. In addition, field studies, such as that of the Lherz massif by Le Roux et al. (2007), have provided direct observational and petrological evidence for the transformation of harzburgites into lherzolites. Such studies have led to an evolution in current understanding of mantle peridotites. The wide range of compositions encountered in ultramafic rock suites is now often attributed to the refertilization of depleted harzburgites by percolating mafic melts, rather than to variable degrees of melt extraction from a putative precursor of primitive mantle composition. (The term "refertilization" as used in this contribution refers to the transformation of harzburgite into lherzolite through percolative magmatic processes.)

Although the importance of refertilization has been increasingly recognized, constraining the timing of such processes remains a critical issue. One possibility is that melt refertilization is 
linked temporally to the original magmatic processes that created the lithosphere. If so, this might imply that refertilization is an intrinsic part of the lithosphere formation mechanism. Alternatively, melt refertilization could be related to tectonic episodes affecting the lithosphere hundreds of millions of years after its formation. In this case, refertilization would have no connection with the original harzburgite-forming melt depletion event. Thus our understanding of how the non-cratonic SCLM formed is deeply dependent on determining when refertilization occurred. Moreover, as depleted harzburgites are less dense than fertile lherzolites (Poudjom Djomani et al., 2001) the timing of refertilization will have significant implications for the stability and long-term survival of the SCLM relative to the convecting mantle.

Osmium isotopes offer the possibility of constraining the timing of refertilization of the SCLM. Since osmium concentrations of peridotites are much higher than those of mantle melts and fluids, the Os isotope compositions of lithospheric peridotites are to some extent protected from modification by metasomatic agents that very frequently perturb the $\mathrm{Sr}, \mathrm{Nd}$ and $\mathrm{Pb}$ isotope compositions of these rocks. Results from dozens of Re-Os studies of orogenic massifs and ultramafic xenoliths derived from the SCLM are now available. Modeling these results allows some broad conclusions to be drawn concerning the timing of refertilization of the non-cratonic lithosphere.

\section{A brief overview of the Re-Os isotope system}

The isotope ${ }^{187}$ Os is formed by the $\beta^{-}$decay of ${ }^{187} \mathrm{Re}$, with a half-life of $41.6 \mathrm{Ga}\left(\lambda=1.666 \times 10^{-11}\right.$ $\mathrm{a}^{-1}$; Smoliar et al., 1996). The Re-Os system differs from all other isotope systems commonly used to study mantle geochemistry in that both the parent and the daughter elements have a strong affinity for sulfide. Osmium is an exceptionally chalcophile element, with recent results suggesting $\mathrm{D}^{\text {sulfsil }}$ (sulfide liquid/silicate liquid) values approaching $10^{6}$ (Mungall and Brenan, 2014). This means that during partial melting of peridotite, Os will be retained in the residue as long as the slightest trace of base metal sulfide remains. Furthermore, even after all sulfide is removed, Os remains in the residue in ultratrace platinum group minerals (PGM) such as laurites and alloys (Luguet et al., 2007). In addition, while observational evidence suggests that olivine is not a significant host of Os (Burton et al.,2002; Puchtel et al.,2004), experimental partitioning data for Ir and and $\mathrm{Ru}$, two platinum group elements closely related to Os, indicate that they are mildly compatible in olivine and spinel (see compilation in Brenan et al., 2016). This suggests that Os may also be compatible in these phases under some conditions. For all of these reasons, Os behaves as a highly compatible element during mantle melting. 
The chalcophility of Re is strongly dependant on the fugacities of oxygen and sulfur (Fonseca et al., 2007), and varies systematically with the relative value of these two parameters (Brenan, 2008). As discussed more fully below, Brenan (2008) argues that this relative value is constrained within a limited range under most upper mantle conditions, corresponding to $\mathrm{D}^{\text {sulfsil }}$ values for Re between about 380 and 820 . Given the relatively low abundances of sulfides in mantle peridotites, and the incompatible nature of Re in other upper mantle phases (Mallmann and O'Neill, 2007; see also compilation in Brenan et al., 2016), this means that unlike Os, Re behaves as a moderately incompatible element during mantle melting.

The contrasting behaviors of Re and Os during melting have several consequences. The high compatibility of Os insures that the Os concentrations of peridotites are elevated relative to those of most melts and fluids, offering some degree of protection to ${ }^{187} \mathrm{Os} /{ }^{188} \mathrm{Os}$ ratios from modification during metasomatism. Retention of Os during melting also explains the very low Os concentrations ( $\sim 30 \mathrm{pg} / \mathrm{g}$; Peucker-Ehrenbrink and Jahn, 2001), and thus high Re/Os ratios of the continental crust, which with time have produced very radiogenic crustal Os isotope compositions relative to mantle values. As the estimated Re concentrations of the continental crust ( $\sim 200 \mathrm{pg} / \mathrm{g}$; Peucker-Ehrenbrink and Jahn, 2001) are comparable to mantle values, and the volume of the crust is small compared to that of the mantle, mass balance considerations imply that extraction of the continental crust had little effect on the average Re/Os ratio of the mantle. This is true even if the continental crust is assumed to have been extracted from only the upper mantle, and the resulting upper mantle Re/Os ratio is considered. In consequence, the average ${ }^{187} \mathrm{Os} /{ }^{188} \mathrm{Os}$ ratio of the upper mantle, is expected to be similar to that inferred for the primitive upper mantle (PUM). This is another respect in which the Re/Os system differs from the $\mathrm{Rb} / \mathrm{Sr}$ and $\mathrm{Sm} / \mathrm{Nd}$ isotope systems, for which the average upper mantle isotope ratios differ markedly from the inferred PUM values (Zindler and Hart, 1986). Of course, the inference that the average ${ }^{187} \mathrm{Os} /{ }^{188}$ Os value of the upper mantle should have been only slightly modified by crustal extraction does not imply that the Os composition of the upper mantle is uniform. Substantial heterogeneity is expected within the convecting mantle, notably between depleted residues of melt extraction and recycled oceanic crust, and this is evident in the heterogeneity observed between and among abyssal peridotites and basalts (Becker and Dale, 2016; Gannoun et al., 2016).

In the following discussion, the term primitive upper mantle (PUM) will be preferred to bulk silicate Earth (BSE), though the compositions of the two reservoirs are often taken to be 
equivalent. Unlike the BSE, the PUM is not an actual reservoir, but instead is a theoretical concept referring to the upper part of the mantle prior to its depletion by extraction of the crust. Nevertheless the composition of this theoretical reservoir can be directly characterized by the study of upper mantle samples, while estimation of the BSE composition requires more assumptions about possible meteoritic building blocks. Therefore throughout the discussion the term PUM will be used. No implications are intended regarding possible differentiation of the primordial mantle or the extent to which mantle convection affects the whole rather than the upper part of the mantle.

\section{Os isotope correlations with bulk rock fertility}

It has long been recognized that in many non-cratonic peridotite suites whole rock Os isotope compositions are correlated with indices of fertility, and in fact such correlations were used to estimate the ${ }^{187} \mathrm{Os} /{ }^{188}$ Os composition of the PUM $(\sim 0.1296 \pm 0.008$; Meisel et al., 2001). Such relationships are rarely seen for highly incompatible lithophile elements such as $\mathrm{Sr}, \mathrm{Nd}$ and $\mathrm{Pb}$. Broadly speaking, these relationships result from the contrasting behavior of Re and Os during melt extraction, and are often preserved because of the relative resistance of osmium isotopes to metasomatic modification. In the following discussion, we will use $\mathrm{Al}_{2} \mathrm{O}_{3}$ content as a proxy for bulk peridotite fertility, as aluminum is a major element and bulk rock $\mathrm{Al}_{2} \mathrm{O}_{3}$ data are available for almost all sample suites, but other parameters, such as $\mathrm{MgO}$ and $\mathrm{CaO}$ contents, $\mathrm{Yb}$ and Lu concentrations, olivine Fo\# and spinel Cr\# have also been used as fertility proxies (e.g. Armytage et al., 2014; Byerly and Lassiter, 2012; Gao et al., 2002; Handler et al., 2003; Peslier et al., 2000; Wu et al., 2006). Most of the discussion will center on whole rock ${ }^{187} \mathrm{Os} /{ }^{188} \mathrm{Os}$ compositions, even though it has been demonstrated that large Os isotope variations exist among sulfides from the same rock sample (Alard et al., 2002; Harvey et al., 2011; Luguet and Pearson, 2019) and that the sulfide and Platinum Group Mineral (PGM) phases hosting Os and the other PGE in mantle peridotites display great complexity (Lorand and Luguet, 2016). Reconciliation of this extensive internal heterogeneity in Os host phases and isotope composition with broader whole rock relationships will be discussed below. Nevertheless, the existence of internal heterogeneity should not obscure the fact that systematic correlations between whole rock Os isotope compositions and major element fertility indices are nearly ubiquitous and must be explained.

Osmium isotope results are now available from studies of more than 50 off-cratonic peridotite suites, permitting some broad generalizations to be drawn. Most of the xenolith data 
summarized below were assembled for a recent review article (Luguet and Reisberg, 2016), while the orogenic peridotite data were taken from the references given by Becker and Dale (2016) for settings described in that reference as convergent margin tectonites or continental/continent-ocean transitional tectonites. A complete list of references for both sample types is given in appendix A of the supplemental online material (SOM).

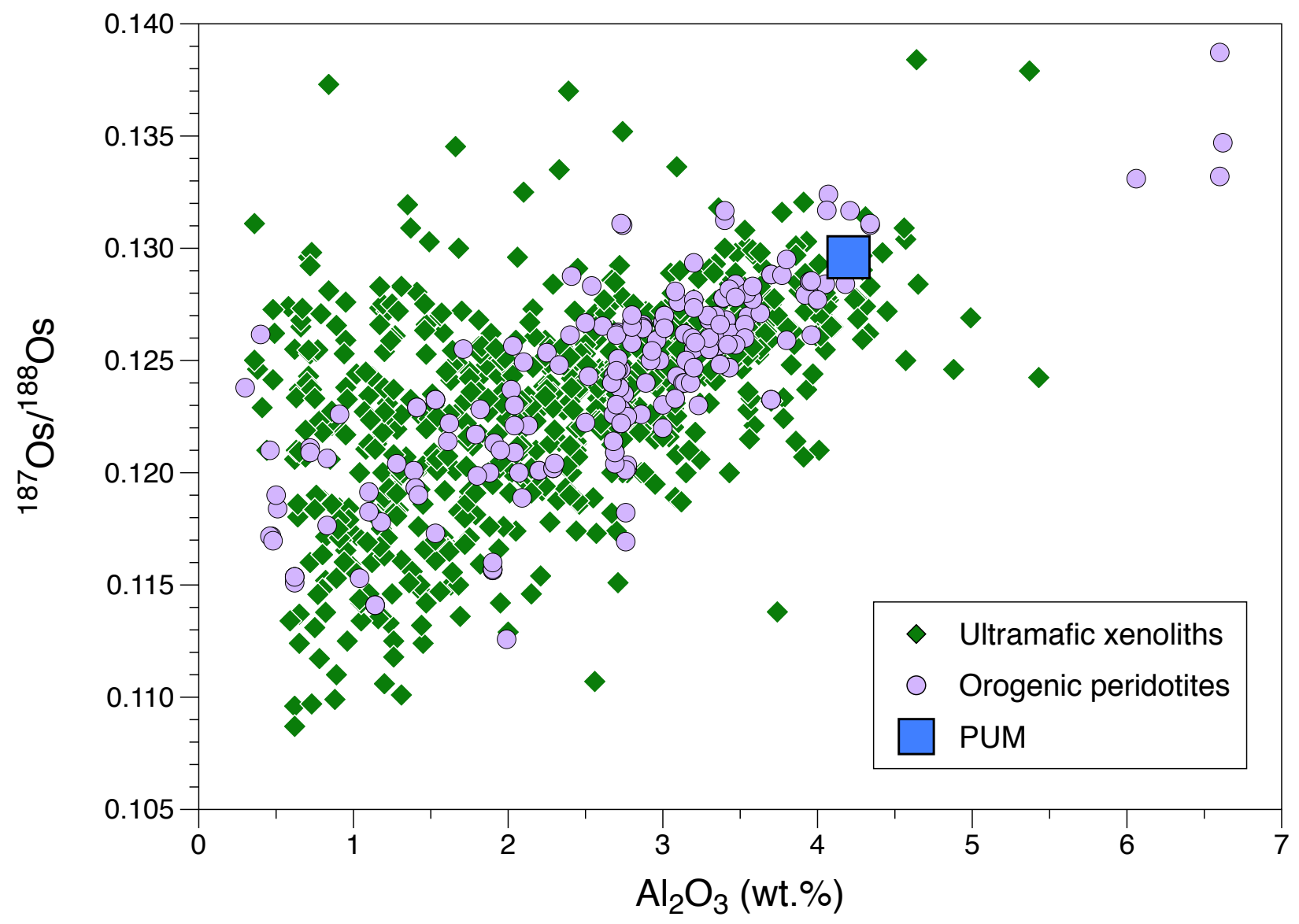

Figure 1. Whole rock ${ }^{187} \mathrm{Os} /{ }^{188} \mathrm{Os}$ ratios as a function of $\mathrm{Al}_{2} \mathrm{O}_{3}$ content for peridotites from the non-cratonic subcontinental lithosphere. Data for ultramafic xenoliths are mostly from the database of Luguet and Reisberg (2016), while those for orogenic peridotites are from settings described as convergent margin tectonites or continental/continent-ocean transitional tectonites by Becker and Dale (2016). The complete list of localities and the corresponding references are given in Appendix A of the supplemental online material (SOM).

All of the ${ }^{187} \mathrm{Os} /{ }^{188} \mathrm{Os}$ data are plotted as a function of $\mathrm{Al}_{2} \mathrm{O}_{3}$ content in Fig. 1. Most of the data lie on a broad trend between highly depleted compositions with unradiogenic ${ }^{187} \mathrm{Os} /{ }^{188} \mathrm{Os}$ values, and fertile lherzolite with an Os isotope composition similar to the Primitive Upper Mantle (PUM) composition defined by (Meisel et al., 2001). Nevertheless, many samples plot substantially above this general trend, particularly among the xenolith data. In contrast, only a few plot significantly below the trend. These tendencies are confirmed by considering the various sample suites individually. Most localities display well defined trends, though the slopes vary between sites. The significance of these trends was evaluated by tracing a line 
between the proposed PUM composition and the least radiogenic sample in each suite (excluding suites with fewer than six samples and those with no samples with $\mathrm{Al}_{2} \mathrm{O}_{3}$ contents less than $2 \%$ ), and determining the deviation in ${ }^{187} \mathrm{Os} /{ }^{188} \mathrm{Os}$ of each sample point from the line. Among xenolith suites, $51 \%$ of the samples were found to plot within $\pm 1.5 \%$ of the trend, while $34 \%$ plot above the trend and only $13 \%$ plot below it. Among orogenic peridotite massifs, $57 \%$ plot within $\pm 1.5 \%$ of the trend, $29 \%$ plot above the trend, and $13 \%$ plot below it. Examples of two xenolith suites are shown in Fig. 2, one from Vitim, Siberia (Pearson et al., 2004) which displays a very strong correlation, and another from Lianshan, eastern China (Reisberg et al., 2005). The latter shows a more typical case of a well-defined correlation coupled with a substantial number of points plotting above the trend. Like many non-cratonic xenolith suites, the Lianshan peridotites have suffered extensive recent Os and Re loss during both pre- and post-eruptive processes. Because of its representative nature, the Lianshan suite will be used as an example in much of the following discussion, but the same conclusions could be drawn from any of the many suites displaying well-defined linear trends passing through the PUM composition.
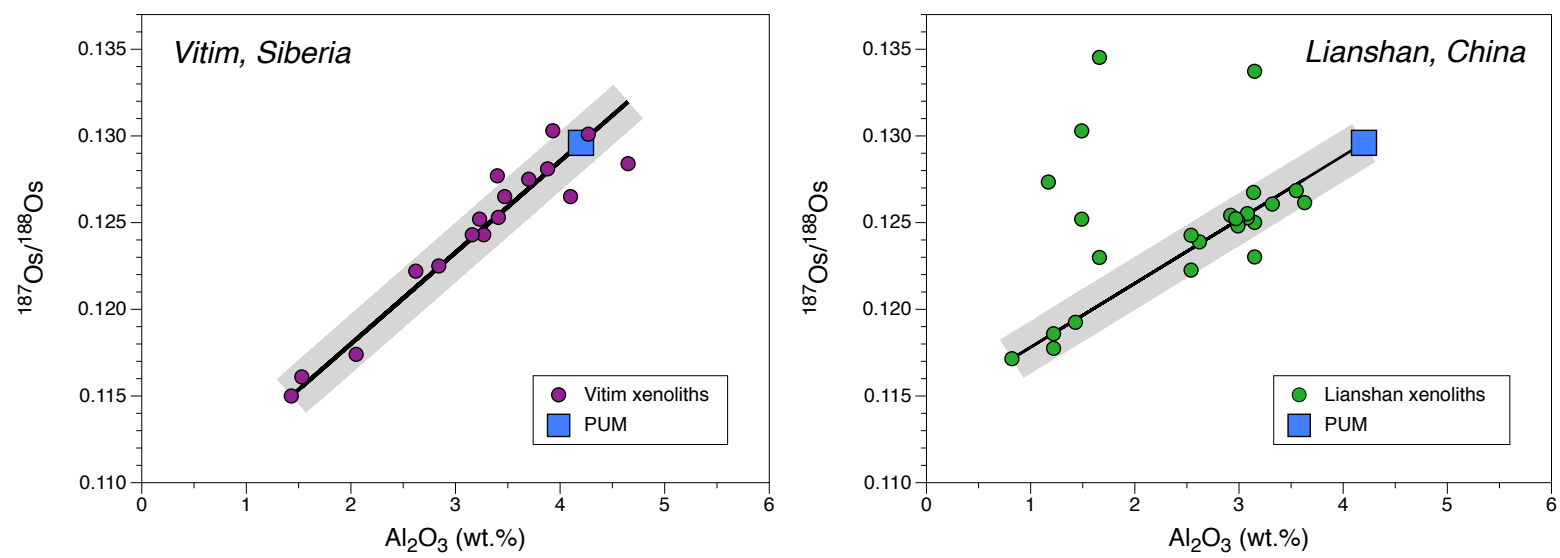

Figure 2. Two examples of peridotite suites showing correlations between ${ }^{187} \mathrm{Os} /{ }^{188} \mathrm{Os}$ and $\mathrm{Al}_{2} \mathrm{O}_{3}$. The large blue square indicates the Primitive Upper Mantle (PUM) composition of Meisel et al. (2001). In both cases, the trend line is drawn between the least radiogenic sample and the PUM composition, and the gray field represents ${ }^{187} \mathrm{Os} /{ }^{188} \mathrm{Os}$ values within $\pm 1.5 \%$ of this line. The samples from Vitim, Siberia studied by Pearson et al. (2004) define an exceptionally good correlation. The samples from Lianshan, China (Reisberg et al., 2005) represent a more typical case, which includes a significant number of samples that plot well above the trend, although most points still plot close to the line. As the Lianshan case is more common, it is used as an example for the modeling, but the same conclusions can be drawn using any of the numerous observed correlations.

\section{What creates correlations between Os isotopes and fertility indices?}

\subsection{Simple mixing between unradiogenic peridotites and radiogenic mafic magmas}


One possible explanation of the observed correlations that can be easily excluded is simple, geologically recent mixing between depleted peridotite and mafic melt. As shown in Fig. 3, such mixing would lead to highly curved trends that do not pass through the PUM value and plot nowhere near the observed correlations. This is because the Os/Al ratios of mafic liquids are much lower than those of peridotites, leading to large increases in $\mathrm{Al}_{2} \mathrm{O}_{3}$ with little change in ${ }^{187} \mathrm{Os} /{ }^{188} \mathrm{Os}$ as melts are added to depleted harzburgite. Thus simple mixing, which in any case is a geologically unrealistic process, cannot explain the observed approximately linear correlations.
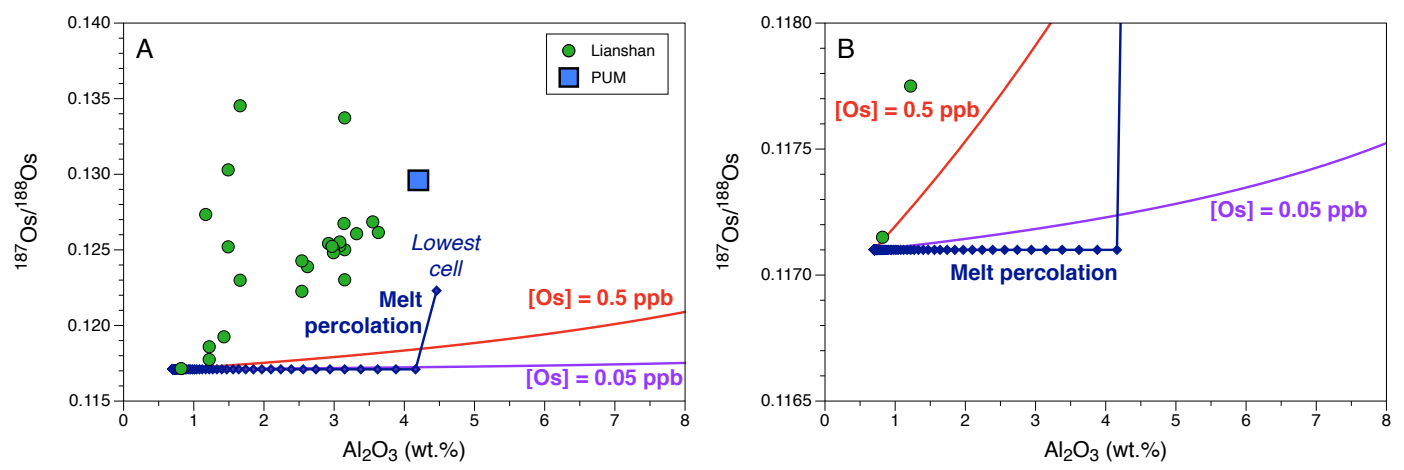

Figure 3. A) Comparison of Lianshan peridotite data (green circles) with mixing curves between depleted peridotite $\left([\mathrm{Os}]=3.5 \mathrm{ppb} ;{ }^{187} \mathrm{Os} /{ }^{188} \mathrm{Os}=0.1171 ; \mathrm{Al}_{2} \mathrm{O}_{3}=0.7 \mathrm{wt} \%\right)$ and mafic melt $\left({ }^{187} \mathrm{Os} /{ }^{188} \mathrm{Os}=0.15 ; \mathrm{Al}_{2} \mathrm{O}_{3}=16 \mathrm{wt} . \%\right)$ with either $0.5 \mathrm{ppb}$ (red curve) or $0.05 \mathrm{ppb}$ (violet curve) of Os. Also shown (see discussion in section 4.3.1) is the curve (dark blue with diamonds) for recent melt percolation (without radiogenic ingrowth of ${ }^{187}$ Os), using the same peridotite and mafic melt parameters, with $[\mathrm{Os}]=0.2 \mathrm{ppb}$ in the melt and assuming a $\mathrm{D}^{\text {sulf } / \text { sil }}$ value of $10^{6}$ for Os. Other parameters are given in Appendix A (SOM). B) Expanded view of (A), showing that recent melt percolation results in an even worse fit than simple mixing, because essentially all osmium is removed from the magma in the lowest step.

\subsection{Radiogenic ingrowth after partial melt extraction}

Another possibility, proposed by Reisberg and Lorand (1995), is that the correlations are essentially isochron analogs, formed by radiogenic ingrowth after ancient partial melting events that left variably depleted peridotites. As discussed above, Re is expected to behave as a moderately incompatible element during partial melting, so Re concentrations in the residue should decrease as melting progresses. Osmium, on the other hand, is highly compatible, so Os contents of peridotites should increase slightly during melting simply due to the removal of Os poor magmas. As a result, Re/Os ratios should decrease during melting concomitantly with fertile melt components, such as $\mathrm{Al}_{2} \mathrm{O}_{3}$. This leads to correlations of Re/Os with $\mathrm{Al}_{2} \mathrm{O}_{3}$, which with time produce correlations between ${ }^{187} \mathrm{Os} /{ }^{188} \mathrm{Os}$ and $\mathrm{Al}_{2} \mathrm{O}_{3}$.

The melting process is explored numerically in Fig. 4, which shows variations in S, Re and Os concentrations of the residue during non-modal batch melting of a spinel peridotite (parameters 
given in figure caption and in Appendix A of SOM; model provided as spreadsheet "non-modal partial melting" in Appendix B of SOM). The model includes silicate phases and spinel as well as sulfide. Rhenium partition coefficients for silicate phases and spinel are based on the work of Mallmann and O'Neill (2007), assuming oxygen fugacity corresponding to the QFM buffer. For osmium, very few results exist for silicate and spinel partitioning, so the values used are based on available ranges compiled by Brenan et al. (2016) for iridium, a closely related element whose abundances are usually well correlated with those of Os in peridotite suites. Nevertheless, though silicate and spinel partitioning are considered in the model, sulfide has by far the largest control on $\mathrm{Re}$ and Os abundances of the residue during melting. Sulfide is progressively removed during melting, to the extent imposed by the SCSS (Sulfur Concentration at Sulfide Saturation) of the magma (Fig. 4a). Rhenium concentrations will decrease with progressive melting (Fig. 4b), as the decreasing sulfide content lowers the Re bulk rock partition coefficient. This figure shows curves corresponding to $\mathrm{D}^{\text {sulf/sil }}$ (sulfide liquid/silicate liquid partition coefficient) values for Re of 820 and 380, which as noted above are the expected upper and lower limits of this parameter for most conditions of mantle melting (Brenan, 2008). The curve corresponding to a $\mathrm{D}^{\text {sulf/sil }}$ value of 380 shows a nearly linear decrease in Re concentration in the residue with increasing melt extraction. In constrast to Re, Os is extremely chalcophile, so it is retained in the residue as long as the slightest trace of sulfide remains (Fig. 4c), and likely even longer if platinum group minerals such as laurite and Os-Ir alloys are exsolved. As magmaphile components are removed, the concentration of Os in the residue increases. As a result of this contrasting behavior, the Re/Os ratio of the residue is negatively correlated with the extent of melt extraction (Fig. $4 \mathrm{~d})$, giving rise with time (1.7 Ga in the example shown), to a positive correlation between ${ }^{187} \mathrm{Os} /{ }^{188} \mathrm{Os}$ and $\mathrm{Al}_{2} \mathrm{O}_{3}$ (Fig. 4e) due to the radioactive decay of ${ }^{187} \mathrm{Re}$. For simplicity, it is assumed here that $\mathrm{Al}_{2} \mathrm{O}_{3}$ decreases linearly with extent of melt extraction, starting with an estimated primitive mantle value of $4.2 \%$ and decreasing to zero at $25 \%$ extraction. The model is continued to $20 \%$ melt extraction, which is equivalent to the point of exhaustion of base metal sulfides in the residue using the chosen parameters; no attempt is made to model greater extents of melting for which Os is dominantly hosted by rare, tiny Platinum Group Minerals (Luguet et al., 2007) or possibly olivine or spinel. $\mathrm{A} \mathrm{D}^{\text {sulf } / \text { sil }}$ value of 380 for Re is used as this best reproduces the linear trends seen in numerous peridotite suites. This $\mathrm{D}^{\text {sulfsil }}$ value for Re also falls within the range (200 to 450) calculated from non-modal batch melting modeling of Re contents in Pyreneen peridotites (Burnham et al., 1998). 
From Fig. 4e, it is apparent that this simple melting model, followed by a prolonged period of radiogenic ingrowth, can successfully reproduce the ${ }^{187} \mathrm{Os} /{ }^{188} \mathrm{Os}$ vs. $\mathrm{Al}_{2} \mathrm{O}_{3}$ trend seen in the Lianshan peridotites. Thus if Os isotopes alone are considered, melt extraction to varying extents followed by ingrowth of ${ }^{187} \mathrm{Os}$ is a viable process for producing the variety of peridotites, ranging in composition from depleted harzburgite to fertile lherzolite, observed in most sample suites.
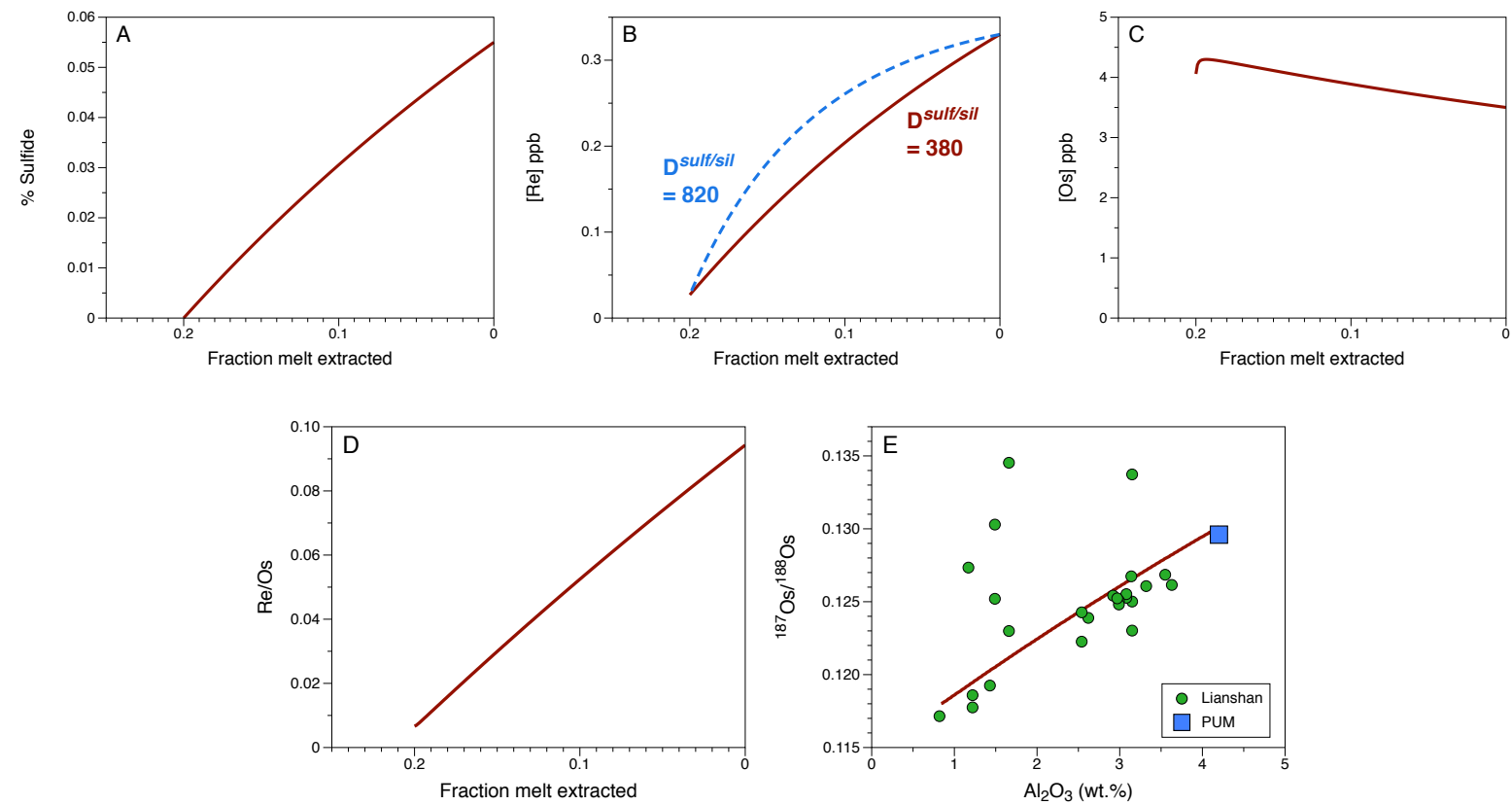

Figure 4. Effects of ancient partial melting of fertile peridotite followed by radiogenic ingrowth producing corelation between ${ }^{187} \mathrm{Os} /{ }^{188} \mathrm{Os}$ and $\mathrm{Al}_{2} \mathrm{O}_{3}$. A) Decrease in sulfide content with increasing fraction of melt extraction (note that melt fraction increases towards the left in this diagram). b) Decrease in [Re] of residue with increasing melt extraction, for $\mathrm{D}^{\text {sulf }} / \mathrm{D}^{\text {sil }}(\mathrm{Re})$ values of 380 and 820 , lower and upper boundaries of range proposed by Brenan (2008). C) Increase in $[\mathrm{Os}]$ of peridotite with increasing melt extraction, assuming $\mathrm{D}^{\text {sulf }} / \mathrm{D}^{\text {sil }}(\mathrm{Os})=10^{6}$. D) Decrease in Re/Os with progressive melt extraction for case of $\mathrm{D}^{\text {sulf }} / \mathrm{D}^{\text {sil }}=380$ for Re. E) ${ }^{187} \mathrm{Os} /{ }^{188} \mathrm{Os}$ vs. $\mathrm{Al}_{2} \mathrm{O}_{3}$ correlation after $1.7 \mathrm{Ga}$ of radiogenic ingrowth compared with Lianshan samples, assuming initial ${ }^{187} \mathrm{Os} /{ }^{188} \mathrm{Os}$ of 0.1171 , the PUM value at $1.7 \mathrm{Ga}$. A non-modal batch partial melting model is used and $\mathrm{Al}_{2} \mathrm{O}_{3}$ is taken to decrease linearly with extent of melting from fertile peridotite with $4.2 \% \mathrm{Al}_{2} \mathrm{O}_{3}$ to $0 \%$ at $25 \%$ melting. Other parameters are given in Appendix A (SOM).

\subsection{Transformation of harzburgite to lherzolite by refertilization}

Though radiogenic ingrowth after ancient melt extraction can potentially explain the observed whole rock Os systematics, this explanation is unlikely to be applicable to all or even most cases. Abundant evidence now exists to suggest that many fertile lherzolites are not simple partial melting residues but are instead formed by the refertilization of harzburgites. This evidence, summarized by Bodinier and Godard (2014), includes structural observations of lherzolites replacing harzburgites, as in the Lherz massif (Le Roux et al., 2007), mineral phase compositions that are inconsistent with trends expected from melt extraction, and textural evidence for crystallization of secondary phases from percolating melts, often in the form of 
intergranular pyroxene and spinel. Intergranular sulfides, notably pentlandite as well as chalcopyrite and pyrrhotite (Lorand and Luguet, 2016; Luguet and Pearson, 2019), are often associated with the precipitated pyroxene and spinel. As sulfides are the main hosts for Re and Os in peridotites, a simple model was developed in order to explore whether the observed ${ }^{187} \mathrm{Os} /{ }^{188} \mathrm{Os}$ vs. $\mathrm{Al}_{2} \mathrm{O}_{3}$ trends could be produced by the simultaneous precipitation of pyroxene, spinel and sulfide during melt percolation. Refertilization models of this type are meltconsuming (Bodinier and Godard, 2014) and will lead to an increase in peridotite volume due to the addition of these precipitated phases.

In the model, mafic magmas percolate upwards in a cooling lithosphere composed of depleted harzburgite. The partial melting event that formed the residual harzburgite is assumed to have been sufficiently profound to approximately homogenize the Os isotopic composition at the scale of the melting region, which is assumed to have followed the average upper mantle evolution path. Though sometimes not stated explicitly, this assumption of homogenization to an average mantle composition is inherent in all model age scenarios. A key feature of the model is that as spinel and pyroxene crystallize, the sulfur content of the magma will increase, leading to sulfur saturation when the SCSS is exceeded. The exsolved sulfide liquid will concentrate Os, and to a lesser extent Re, from the silicate liquid. A simplified plate model, composed of 100 stacked cells, is assumed. For each added melt increment, after pyroxene and spinel precipitation provoke exsolution of a sulfide liquid, Re and Os are allowed to equilibrate between all of these newly-formed phases and the remaining silicate liquid. (A variant of the model, in which the Re and Os in the liquid equilibrate with all of the phases present in the rock, is considered below.) This silicate liquid then migrates upward while the sulfide liquid remains behind because of its greater density. To start the next step, new silicate magma is added from below. No attempt is made to thermodynamically model changes in the major element composition of the bulk rock or the individual phases, as this would be far beyond the scope of this contribution. Instead, $\mathrm{Al}_{2} \mathrm{O}_{3}$ is used as an index of the extent of refertilization, that is, alumina content is assumed to increase linearly with addition of precipitating phases from the percolating magma. This is achieved by adjusting the modal proportions of the crystallizing phases to assure that the $\mathrm{Al}_{2} \mathrm{O}_{3}$ content of the magma remains constant. As shown in Appendix A (SOM), the modal compositions of fertile lherzolites produced by the model are not unreasonable, suggesting that this approximation is adequate for the purpose of modeling the behavior of the Re-Os system during melt percolation. 
The parameters and assumptions of the model are explained in more detail in Appendix A. A spreadsheet is provided in Appendix B (SOM) that can be used to investigate the effects of modifying the inputs. This simple percolation model is used to test two cases: that of recent refertilization in which the unradiogenic harzburgite interacts with a melt of radiogenic Os composition, and that of ancient refertilization in which Re is added and the range of ${ }^{187} \mathrm{Os} /{ }^{188} \mathrm{Os}$ ratios is acquired through radiogenic ingrowth.

\subsubsection{Can recent melt percolation transform ancient harzburgites into lherzolites?}

The first case concerns refertilization episodes that are geologically recent, or at least much younger than and unrelated to the original profound melting events that depleted the harzburgites. In this case, the correlations between Os isotope compositions and whole rock fertility would have to reflect addition of sulfides with radiogenic Os derived from the melt together with addition of spinel and pyroxene. However, because of the extreme chalcophility of Os ( $\mathrm{D}^{\text {sulf } / \text { sil }} \sim 10^{6}$; Mungall and Brenan, 2014), essentially all of the Os would be incorporated into sulfides in the bottom-most increment of the percolation column (Fig. 5a). In the overlying increment, almost no Os is added, and the bulk rock Os concentration is decreased by the addition of Os-free spinel and pyroxene. As the amount of material added decreases with height in the column, this dilution effect becomes progressively less important moving upwards. Since, with the exception of the lowest step, no radiogenic Os is added as the melts migrate up the column, nearly horizontal arrays are produced on ${ }^{187} \mathrm{Os} /{ }^{188} \mathrm{Os}$ vs. $\mathrm{Al}_{2} \mathrm{O}_{3}$ diagrams (Fig. 3). This is true even for parameter choices most likely to favor the imprint of a radiogenic signature on the peridotites (percolating magma with exceptionally high Os concentration and radiogenic composition). These arrays deviate even more strongly from the data than the trends for the case of simple mixing also shown in Fig. 3, because exsolution of a sulfide liquid will rapidly strip essentially all of the Os from the percolating silicate melt. Though the partition coefficient is less well constrained, spinel also likely incorporates Os (Harvey et al., 2011), reinforcing the compatible behavior of this element. Thus not only are the percolating magmas likely to start with low Os concentrations relative to those of peridotites, but also any Os contained in these melts will be trapped by sulfides and possibly spinel at the very bottom of the column. 

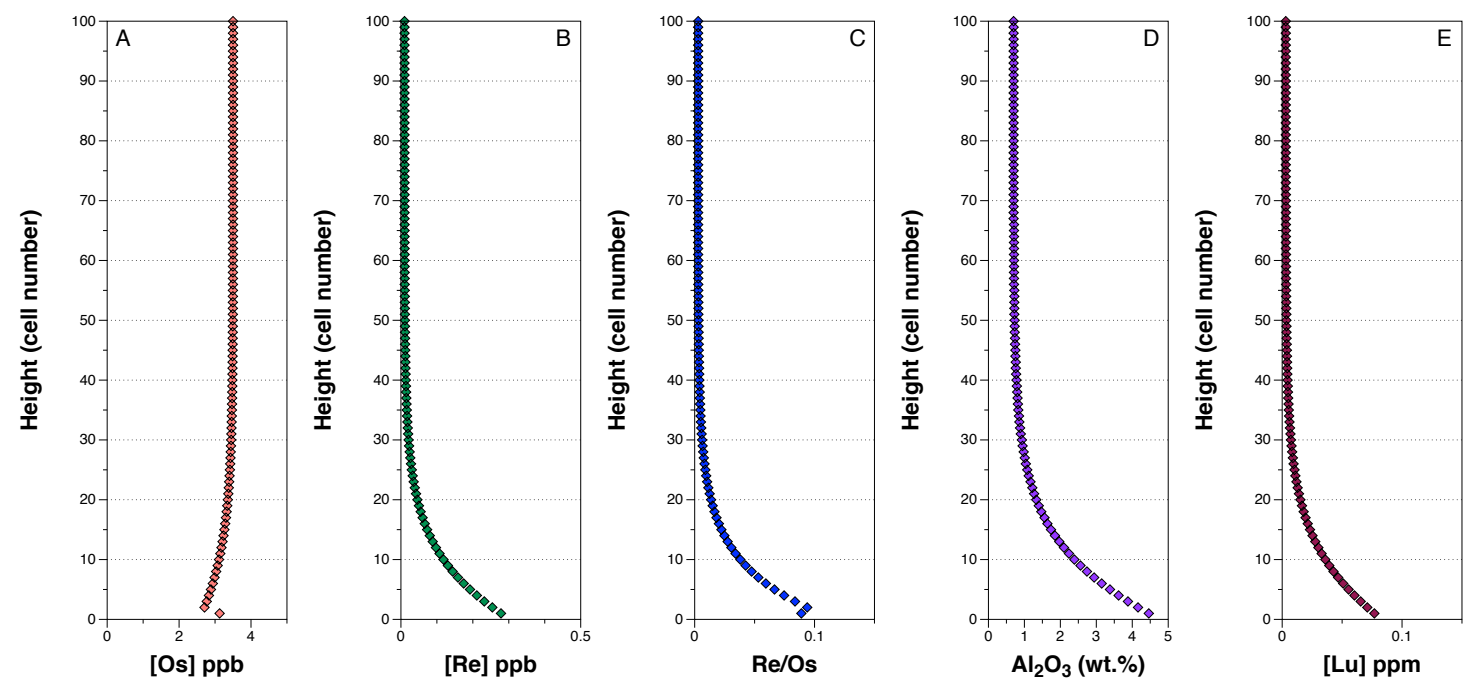

Figure 5. Modeled variation in whole rock [Os], $[\mathrm{Re}], \mathrm{Re} / \mathrm{Os}, \mathrm{Al}_{2} \mathrm{O}_{3}$ and $[\mathrm{Lu}]$ produced by melts percolating upwards in a harzburgite column. Assumed parameters are given in Appendix A (SOM).

The nearly horizontal trends that recent melt percolation would predict (Fig. 3) are seldom, if ever, seen in peridotite suites (Fig. 1). If radiogenic Os were added long after the original melt depletion event that created the harzburgites, but nevertheless several hundred million years before the present, moderately sloped trends might be expected to result from these initially horizontal trends because of the effect of radiogenic ingrowth of ${ }^{187}$ Os. However such trends would not pass through the PUM value, and would be notably less steep than the observed trends.

Another argument against addition of radiogenic sulfides concomitantly with precipitation of spinel and pyroxene is that under this scenario the observed ${ }^{187} \mathrm{Os} /{ }^{188} \mathrm{Os} \mathrm{vs} . \mathrm{Al}_{2} \mathrm{O}_{3}$ correlations would require Os concentrations to increase systematically with $\mathrm{Al}_{2} \mathrm{O}_{3}$, which is not observed. Fig. 6 shows the increase in [Os] in the peridotites that would result if the observed ${ }^{187} \mathrm{Os} /{ }^{188} \mathrm{Os}$ vs. $\mathrm{Al}_{2} \mathrm{O}_{3}$ trends were formed by addition of radiogenic sulfides of three different assumed Os isotope compositions. To trace these curves, the value of ${ }^{187} \mathrm{Os} /{ }^{188} \mathrm{Os}$ corresponding to each radiogenic Os that would have to be added to reach each ${ }^{187} \mathrm{Os} /{ }^{188} \mathrm{Os}$ value was calculated. The steepness and curvature of the required increase of [Os] with $\mathrm{Al}_{2} \mathrm{O}_{3}$ depends on the ${ }^{187} \mathrm{Os} /{ }^{188} \mathrm{Os}$ composition of the added sulfides, as less osmium is required if its composition is more radiogenic. This figure implies that lherzolites should have systematically higher Os contents than harzburgites, which is seldom, if ever, the case in peridotite suites (see examples of Os concentration variations with $\mathrm{Al}_{2} \mathrm{O}_{3}$ in Fig. 4 of Luguet and Reisberg, 2016). The near absence of examples of suites in which [Os] increases with $\mathrm{Al}_{2} \mathrm{O}_{3}$, in addition to the absence of horizontal relationships between ${ }^{187} \mathrm{Os} /{ }^{188} \mathrm{Os}$ and $\mathrm{Al}_{2} \mathrm{O}_{3}$, leads to the conclusion that large scale 
refertilization of ancient depleted harzburgites to form lherzolites during much younger melt percolation is a process that almost never occurs.

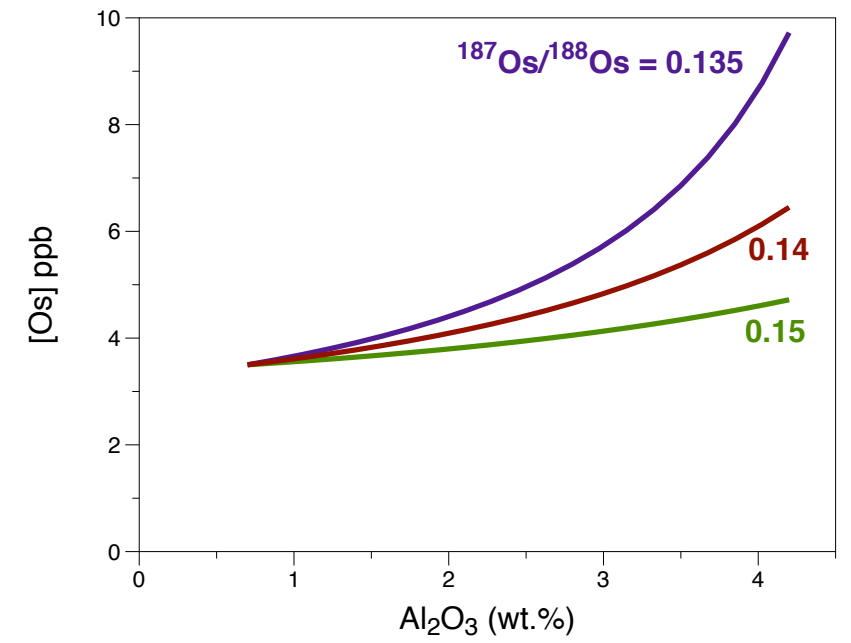

Figure 6. Increase of bulk rock [Os] with $\mathrm{Al}_{2} \mathrm{O}_{3}$ content required to produce linear correlations between ${ }^{187} \mathrm{Os} /{ }^{188} \mathrm{Os}$ and $\mathrm{Al}_{2} \mathrm{O}_{3}$, if it is assumed that such correlations can be produced by simple addition of radiogenic sulfides together with spinel and pyroxene to depleted, unradiogenic harzburgite. Spreadsheet showing calculation is included in Appendix B (sheet "Rad sulfide addition"). Numbers on curves indicate assumed ${ }^{187} \mathrm{Os} /{ }^{188} \mathrm{Os}$ ratios of added sulfides. In the linear correlation on which these curves are based, the harzburgic endmember is assumed to have ${ }^{187} \mathrm{Os} /{ }^{188} \mathrm{Os}=$ 0.117 , [Os] $=3.5 \mathrm{ppb}$, and $\mathrm{Al}_{2} \mathrm{O}_{3}=0.7 \mathrm{wt} . \%$, and the PUM is assumed to have ${ }^{187} \mathrm{Os} /{ }^{188} \mathrm{Os}=0.1296$ and $\mathrm{Al}_{2} \mathrm{O}_{3}$ $=4.2 \mathrm{wt} . \%$. Positive co-variations between [Os] and $\mathrm{Al}_{2} \mathrm{O}_{3}$ are rarely (if ever) observed in peridotite suites.

\subsubsection{Refertilization soon after melt extraction followed by radiogenic ingrowth}

The second case to be tested is whether melt percolation occurring soon after melt extraction is likely to produce covariations between $\mathrm{Re} / \mathrm{Os}$ and $\mathrm{Al}_{2} \mathrm{O}_{3}$, which would over time produce correlations between ${ }^{187} \mathrm{Os} /{ }^{188} \mathrm{Os}$ and $\mathrm{Al}_{2} \mathrm{O}_{3}$ by radiogenic ingrowth. Fig. 5b shows how $\mathrm{Re}$ contents vary with height after melt percolation in the column. A $\mathrm{D}^{\text {sulf } / \text { sil }}$ value of 380 , which yielded the best results in the simple partial melting model is assumed in the case shown. Re concentrations are highest in the lowest step and decrease gradually with height towards the original harzburgite value. Thus the Re profile with depth contrasts markedly with that of Os, as a result of the difference in degree of chalcophility of the two elements. Fig. 5 also shows the $\mathrm{Re} / \mathrm{Os}$ ratio as a function of height in the column, as well as the variation in $\mathrm{Al}_{2} \mathrm{O}_{3}$ content that results from the precipitation of pyroxene and spinel. It is apparent from this figure that with the exception of the lowest, most fertile Os-rich step, $\mathrm{Re} / \mathrm{Os}$ and $\mathrm{Al}_{2} \mathrm{O}_{3}$ covary in a coherent manner. This leads to a nearly linear correlation between these two parameters, which with time will develop into a correlation between ${ }^{187} \mathrm{Os} /{ }^{188} \mathrm{Os}$ and $\mathrm{Al}_{2} \mathrm{O}_{3}$ (Fig. 7a and 7b). In Fig. 7b, an age of $1.7 \mathrm{Ga}$ was used to calculate the ${ }^{187} \mathrm{Os} /{ }^{188} \mathrm{Os}$ ratios, based on the Re depletion model age $\left(\mathrm{T}_{\mathrm{RD}}\right.$; Walker et al., 1989) of the most depleted harzburgite. $\mathrm{T}_{\mathrm{RD}}$ ages are obtained by comparing the measured ${ }^{187} \mathrm{Os} /{ }^{188} \mathrm{Os}$ values directly with the Os mantle evolution curve, and so intrinsically assume a Re content of zero for each sample before its emplacement at the surface. Therefore, $\mathrm{T}_{\mathrm{RD}}$ ages are always minimum values. Nevertheless, $\mathrm{T}_{\mathrm{RD}}$ ages should closely approximate melt extraction ages in the case of highly depleted harzburgites, as these rocks are expected to have lost nearly all of their Re during partial melting. 



Figure 7. A) Expected correlation between ${ }^{187} \mathrm{Re} /{ }^{188} \mathrm{Os}$ and $\mathrm{Al}_{2} \mathrm{O}_{3}$, resulting from their coherent evolution with depth in the percolation column shown in Fig. 5. B) With time (1.7 Ga for the Lianshan samples, based on the ${ }^{187} \mathrm{Os} /{ }^{188} \mathrm{Os}$ and corresponding $\mathrm{T}_{\mathrm{RD}}$ of the least radiogenic harzburgite) this results in a correlation between ${ }^{187} \mathrm{Os} /{ }^{188} \mathrm{Os}$ and $\mathrm{Al}_{2} \mathrm{O}_{3}$ that passes through most of the Lianshan samples, as well as the PUM value. C) Expected correlation between ${ }^{187} \mathrm{Re} /{ }^{188} \mathrm{Os}$ and $[\mathrm{Lu}]$, assuming that the added $\mathrm{Al}_{2} \mathrm{O}_{3}$ bearing phases are equally divided between spinel and garnet. D) Resulting correlation between ${ }^{187} \mathrm{Os} /{ }^{188} \mathrm{Os}$ and $\mathrm{Lu}$ compared with Lianshan data. Purple curve with diamonds represents precipitation of equal amounts of spinel and garnet. Red dashed curved shows case where the added alumina-bearing phase is composed only of spinel; gray dashed curve shows case where this phase is composed only of garnet. Model parameters are given in Appendix A.

The sensitivity of the model to the choice of parameters is explored extensively in Appendix A of the SOM. Broadly speaking three types of behavior are observed, if parameter choices are kept within limits appropriate for the upper mantle excluding highly oxidized arc environments. The first consists of parameters that have a nearly negligible $\left(\mathrm{D}_{\mathrm{Os}}{ }^{\text {sulfsil }}, \mathrm{K}_{\mathrm{d}} \mathrm{Os}_{c p x}, \mathrm{~K}_{\mathrm{d}} \mathrm{Os}_{s p}, \mathrm{~K}_{\mathrm{d}} \mathrm{Re}_{s p}\right.$, $\left.[\mathrm{Os}]_{\text {liq }},[\mathrm{Os}]_{\text {perid }}\right)$ or minor $\left(\mathrm{K}_{\mathrm{d}} \mathrm{Re}_{c p x}, \mathrm{~K}_{\mathrm{d}} \mathrm{Re}_{\text {gt }},[\mathrm{Re}]_{\text {liq }}\right.$, $\left.[\mathrm{Os}]_{\text {perid }}, \mathrm{Al}_{2} \mathrm{O}_{3 l i q}, \mathrm{SCSS}\right)$ effect on the slope, curvature or extent of the calculated curves. An example of this group (SCSS) is shown in Fig. $8 \mathrm{a}-\mathrm{c}$, for SCSS values varying from 1200 to $800 \mathrm{ppm}$, which corresponds roughly to depths of 0 to $120 \mathrm{~km}$ (Li and Ripley, 2005) since this parameter is sensitive to pressure. Optimal results are found for a SCSS value of $\sim 1000 \mathrm{ppm}$, but the variation of the curve throughout this range is limited. The second group consists of parameters that control the extent of refertilization, but 
that have very little effect on the slope of the ${ }^{187} \mathrm{Os} /{ }^{188} \mathrm{Os}$ vs. $\mathrm{Al}_{2} \mathrm{O}_{3}$ correlation. These parameters include initial melt fraction (porosity) of the bottom cell, fraction of silicate/spinel crystallization in each increment, and the number of times new increments of melt are added to the bottom of the column. As shown for the example of initial melt fraction (Fig. 8d-f), these parameters have a very strong effect on the range of the calculated trend, but have only a minor effect on its slope.
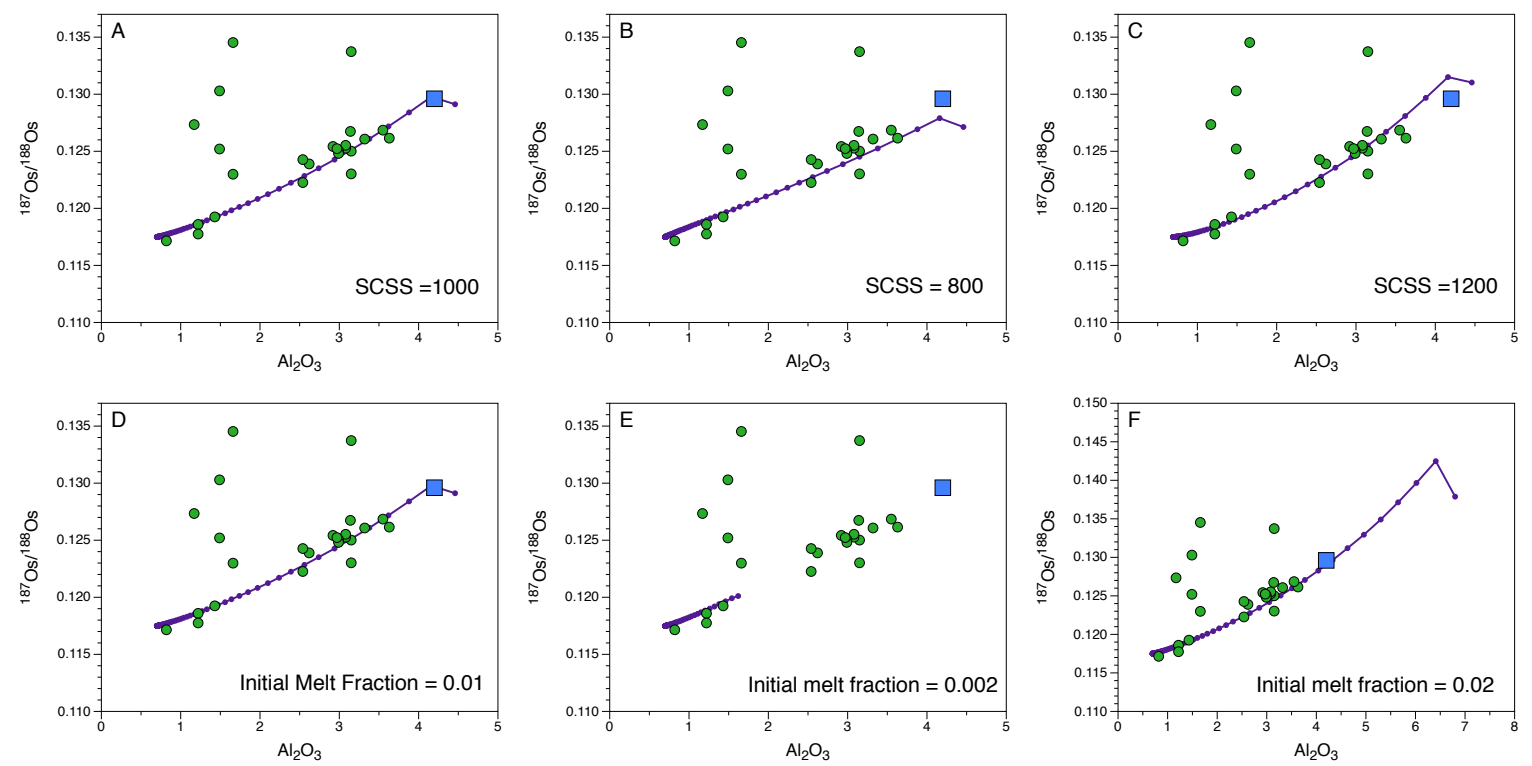

Figure 8. Parameter tests of the percolation model, considering ancient Re addition followed by radiogenic ingrowth of ${ }^{187}$ Os. A-C) Example of a parameter (SCSS, Sulfur Concentration at Sulfide Saturation) that has only limited effect on either the slope or the extent of the calculated trend. SCSS is allowed to vary between 800 and $1200 \mathrm{ppm}$, which corresponds to depths of roughly 120 to $0 \mathrm{~km}$ (Li and Ripley, 2005). Though an optimal fit to the Lianshan data is found for SCSS $\sim 1000$, variation within the tested range has only a minor effect on the results. D-F) Example of a parameter (initial melt fraction) that has very little effect on the slope or curvature of the calculated refertilization trend, but a large effect on its extent. Sensitivity tests for other model parameters are presented in Appendix A.

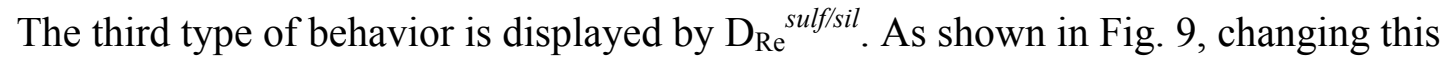
parameter within the limits for this value proposed in the literature has a dramatic effect on the form of the curve relating ${ }^{187} \mathrm{Os} /{ }^{188} \mathrm{Os}$ to $\mathrm{Al}_{2} \mathrm{O}_{3}$. At very low $\mathrm{D}_{\mathrm{Re}}{ }^{\text {sulfsil }}$, such as the value of 40 suggested by Roy Barman et al. (1998) on the basis of Re contents in sulfide globules and their host basaltic glasses, a very shallow, slightly convex upwards trend is observed that falls far below the data points (Fig. 9a). In contrast, the very high $\mathrm{D}_{\operatorname{Re}}{ }^{\text {sulfsil }}$ values of $\sim 40,000$ suggested by the experimental work of Sattari et al. (2002) yield extremely concave upward curves that also deviate greatly from the data (Fig. 9d). As discussed by Fonseca et al. (2007), the great range in $\mathrm{D}_{\mathrm{Re}}{ }^{\text {sulf/sil }}$ obtained from experimental studies reflects the sensitivity of this parameter to $f \mathrm{~S}_{2}$ and $f \mathrm{O}_{2}$. Brenan (2008) noted that a systematic relationship exists between $\mathrm{D}_{\mathrm{Re}}{ }^{\text {sulfsil }}$ and the relative value of these two parameters, expressed as $1 / 2 \log f \mathrm{~S}_{2}-1 / 2 \log f \mathrm{O}_{2}$. He emphasized 
that $f \mathrm{~S}_{2}$ and $f \mathrm{O}_{2}$ are linked in mantle melts by a heterogeneous equilibrium reaction relating $\mathrm{FeO}$ in the silicate liquid to $\mathrm{FeS}$ in the sulfide liquid. As $\mathrm{FeO}$ contents in primary mafic magmas are confined to a limited range, the value of $1 / 2 \log f \mathrm{~S}_{2}-1 / 2 \log f \mathrm{O}_{2}$ is also confined to a restricted range. The limits of this range correspond to $\mathrm{D}_{\mathrm{Re}}{ }^{\text {sulfsil }}$ values of about 380 to 820 for primary magmas with $\mathrm{FeO}$ contents of $11 \%$ and $8 \%$, respectively (Brenan, 2008). Figs. 9b and $9 c$, respectively, compare model curves constructed with these $\mathrm{D}_{\mathrm{Re}}{ }^{\text {sulfsil }}$ values to the test data from Lianshan. It is apparent that $\mathrm{D}_{\mathrm{Re}}{ }^{\text {sulf/sil }}$ values toward the lower end of this range, which should be associated with primary magmas with high $\mathrm{FeO}$ contents, produce curves that closely fit the data. As the FeO contents of primary magmas increase with pressure (Jaques and Green, 1980), it is plausible that melts circulating in the lower part of the lithosphere would be iron rich, and would thus have the relatively low $\mathrm{D}_{\operatorname{Re}}{ }^{\text {sulf/sil }}$ values required to fit the data.
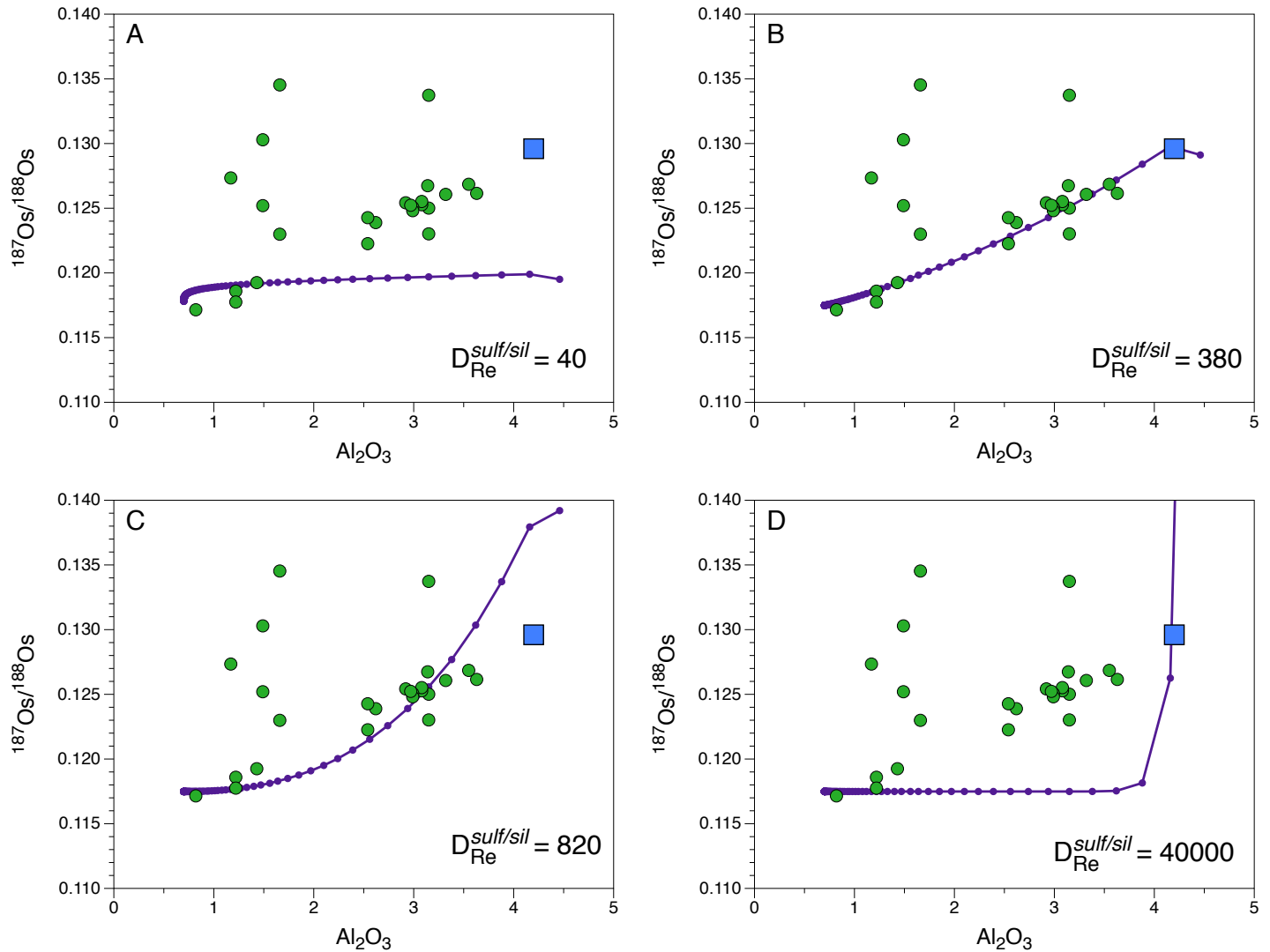

Figure 9. Dependence of modeled refertilization trend (after radiogenic ingrowth) on $\mathrm{D}_{\operatorname{Re}}{ }^{\text {sulfsil }}$. A) $\mathrm{D}_{\operatorname{Re}}{ }^{\text {sulfsil }}=40$, value suggested by analyses of sulfide globules and their host basaltic glasses (Roy-Barman et al., 1998). B) $\mathrm{D}_{\mathrm{Re}}{ }^{\text {sulf } / \text { sil }}=380$, lower limit of range suggested by Brenan (2008), corresponding to high FeO primary melts. This provides the best fit to the data and is the default value used in the text. C) $\mathrm{D}_{\mathrm{Re}}{ }^{\text {sulfsil }}=820$, upper limit of range suggested by Brenan (2008), corresponding to low $\mathrm{FeO}$ basalts. d) $\mathrm{D}_{\mathrm{Re}}{ }^{\text {sulfsil }}=40000$, suggested by experimental work of Sattari et al. (2002).

It thus appears that refertilization following soon after the original melting event can indeed successfully explain the existence of correlations between Os isotope composition and fertility that are nearly ubiquitous in the whole rock record from the non-cratonic subcontinental 
lithospheric mantle. This is perhaps not surprising as the massive partial melting episodes needed for large scale development of depleted harzburgites are unlikely to stop abruptly. Instead a cooling period would be expected, and during this time melts from the still hot underlying regions could migrate up through the cooling lithosphere, transforming harzburgites into lherzolites. Some support for ancient refertilization comes from the recent study by Le Roux et al. (2016) of websterite layers in the Lherz massif, which are thought to have been formed by the same refertilization process that produced the lherzolites. Using a combination of methods, these authors proposed a refertilization age of 1.5 to $1.8 \mathrm{Ga}$, much older than the late Variscan age originally postulated for this process (Le Roux et al., 2007). This new age overlaps with the Os $\mathrm{T}_{\mathrm{RD}}$ model age $(1.75-2.07 \mathrm{Ga})$ that can be calculated from the ${ }^{187} \mathrm{Os} /{ }^{188} \mathrm{Os}$ ratio $(0.1151)$ of the most refractory harzburgite studied from the massif (Reisberg and Lorand, 1995). The age suggested by Le Roux et al. (2007) also agrees with the Os model age of 1.9 \pm 0.3 Ga calculated by Burnham et al. (1998) for the eastern Pyrenean massifs. This agreement suggests that melt extraction, followed soon after by refertilization, is the process that produced the lherzolites in the type locality of this lithology.

\section{Correlations with heavy Rare Earth Elements}

In addition to $\mathrm{Al}_{2} \mathrm{O}_{3}$, the heavy Rare Earth Elements (HREE) Lu and $\mathrm{Yb}$ are sometimes used as fertility indices in ultramafic rocks, and their contents often correlate with ${ }^{187} \mathrm{Os} /{ }^{188} \mathrm{Os}$ ratios in samples from the non-cratonic mantle lithosphere (e.g. Armytage et al., 2014; Peslier et al., 2000). The most important factor controlling HREE behavior in upper mantle magmatic processes is the presence and abundance of garnet, as the HREE are compatible in this phase. Though the depth of the spinel-garnet transition will depend on temperature and peridotite composition (Ionov et al., 1993; Wood et al., 2013), garnet is usually stable at depths greater than $\sim 70 \mathrm{~km}$. Thus the model was adapted to test whether melt percolation in the garnet stability field could produce the observed correlations of Lu with ${ }^{187} \mathrm{Os} /{ }^{188} \mathrm{Os}$.

Results of the modeling are shown in Fig. 7, and compared with the data from Lianshan. In this dataset, ${ }^{187} \mathrm{Os} /{ }^{188}$ Os correlates less well with $\mathrm{Lu}$ than with $\mathrm{Al}_{2} \mathrm{O}_{3}$, reflecting the considerable scatter in the relationship between $\mathrm{Lu}$ and $\mathrm{Al}_{2} \mathrm{O}_{3}$. Nevertheless, the approximately half of the data that are well aligned in Fig. 7d are fairly well fit by the model using the chosen parameters. The model partition coefficients for $\mathrm{Lu}$ in silicate phases and spinel were taken from McKenzie and O'nions (1991) as these are internally consistent, but the exact choice of $\mathrm{K}_{\mathrm{d}}(\mathrm{Lu})$ values has only a limited effect on the model results. On the other hand, the model results are highly sensitive to the relative proportions of the main $\mathrm{Al}_{2} \mathrm{O}_{3}$ bearing phases, spinel 
and garnet (Fig. 7d). If only spinel is present the calculated curve is strongly concave up. Conversely if only garnet is present, the curve is strongly concave down. Neither case fits the data. In contrast, similar modal abundances of garnet and spinel produce an approximately linear correlation that passes through or close to the aligned data. It should be noted that garnet is not observed in the thin sections of the Lianshan xenoliths (Reisberg et al., 2005). This might suggest that the source of these xenoliths experienced melt percolation near the spinelgarnet transition, and was subsequently uplifted into the spinel peridotite facies.

The inferred presence of both spinel and garnet suggests melt percolation in the mid to lower non-cratonic lithosphere. This is consistent with the conclusion drawn above from the optimal Re partition coefficient $(\sim 380)$, which suggests interaction with melts with high $\mathrm{FeO}$ contents, as might be expected at mid to lower lithospheric depths. It is also consistent with the fact that the data are best fit in the ${ }^{187} \mathrm{Os} /{ }^{188} \mathrm{Os}$ vs. $\mathrm{Al}_{2} \mathrm{O}_{3}$ diagram (Fig. 8) when a SCSS value of $\sim 1000$ ppm is assumed, which would correspond to a depth of $\sim 60 \mathrm{~km}$ ( $\mathrm{Li}$ and Ripley, 2005). While none of these arguments is definitive, they are all suggestive of melt percolation in the mid to lower part of the non-cratonic lithosphere.

\section{Equilibrium melt percolation model}

In the model discussed above, only local equilibrium was assumed, that is, the Re and Os in the crystallized phases and exsolved sulfide liquid were taken to equilibrate only with the increment of silicate liquid from which these phases formed. This was done for simplicity, as it allowed each increment of liquid to be considered in isolation from the rest of the rock, and the total effect to be obtained simply by multiplying by the number of increments. However in reality, Re and Os in the newly formed phases may fully or partially equilibrate with the phases left by the preceding melt increments, as well as with the phases inherited from the original peridotite. This is more complex to model, as equilibrium concentrations must be calculated using modal proportions that change with each melt increment. Furthermore, the Re and Os concentrations of the liquid passed from any given cell to the overlying cell will change with time, as the modal composition of the peridotite with which the melt equilibrates changes. As a result, a separate spreadsheet is needed for each cell in the percolation column to allow the effects of each increment of melt addition to be calculated individually. For this reason, a full equilibrium model was tested only for the bottom 25 cells of the column, and the number of melt increments was fixed at 320 . 
As can be seen in Fig. 10, the results of the full equilibrium model are almost identical to those of the orignal model based on local equilibration between the melt and the newly formed phases. This is true even if the model parameters are changed, as long as these remain within geologically reasonable limits. The explanation for the good agreement lies in the strong affinity of both Re and Os for sulfides, implying that equilibration with the other phases present in the rock has little effect. If the $\mathrm{D}^{\text {sulfsil }}$ value for Re is decreased to an irrealistically low value (20 in the example shown in Fig. 10c and 10d) not only do both curves plot far from the data, but they diverge substantially from each other. The equilibrium model is provided in Appendix C (SOM). Values are adjustable on the "Summary" sheet and results are directly compared with the original, local equilibrium model.
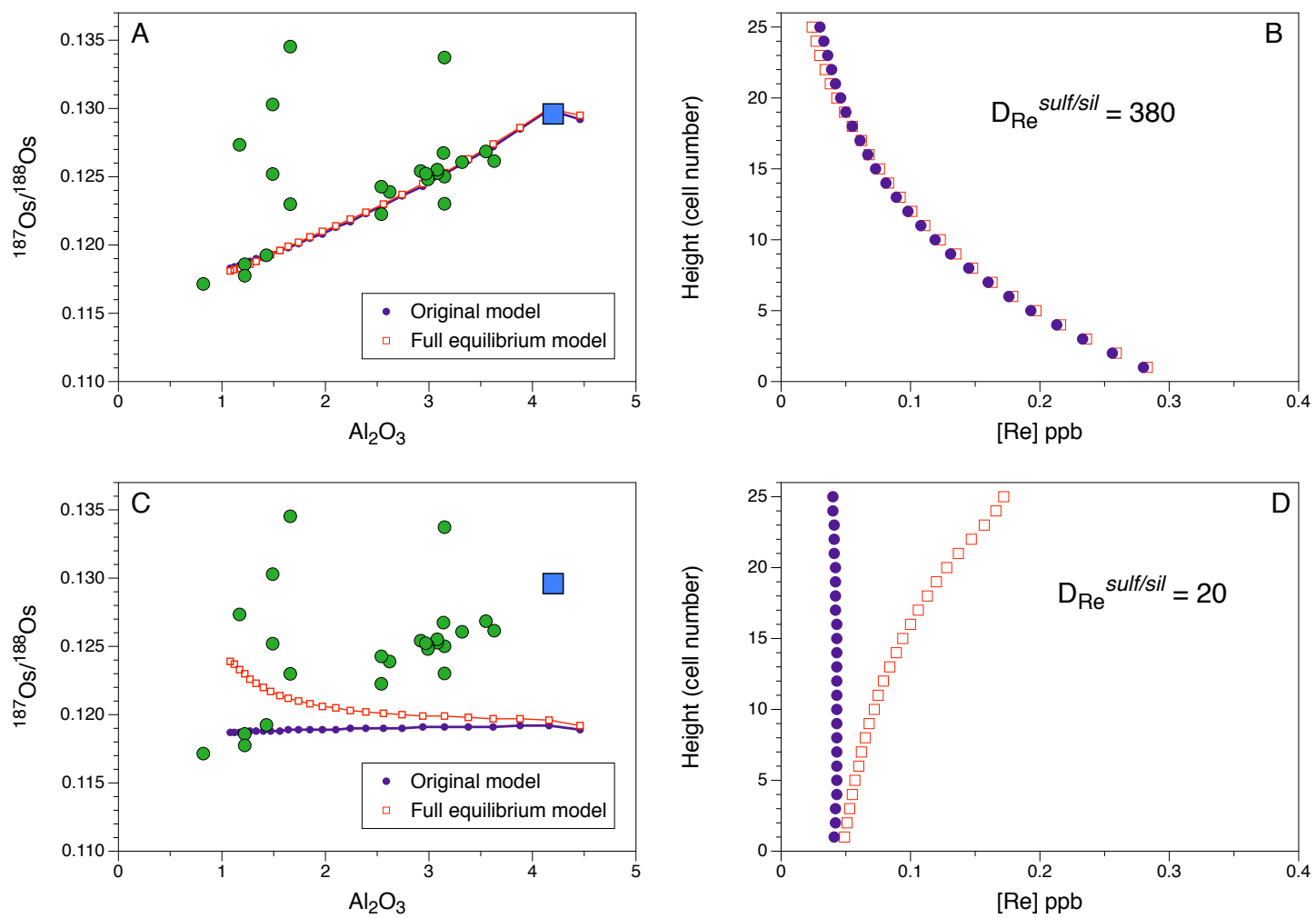

Figure 10. Comparison of local equilibrium (original) model with full equilibrium model. A) If $\mathrm{D}_{\mathrm{Re}}{ }^{\text {sulf } / \text { sil }}=380$, the two models yield nearly indistinguishable results that fit the data well. B) Agreement between the two models reflects their nearly identical Re profiles with height in the column. C) If the assumed $\mathrm{D}_{\mathrm{Re}}{ }^{\text {sulfsil }}=20$, the two curves diverge sharply, and neither fits the data. D) Divergence of the curves reflects a contrast in the Re profiles with height between the two models when the $\mathrm{D}_{\mathrm{Re}}{ }^{\text {sulf } / \text { il }}$ value is low.

\section{Reconciling systematic whole rock Os isotope relationships with internal Os isotope heterogeneity}

The preceding discussion suggests that the frequently observed whole rock correlations of Os isotope compositions with fertility indices in mantle peridotites can by explained by early 
refertilization followed by radiogenic ingrowth. Modeling results suggest that the development of these trends is fairly insensitive to the extent of equilibration with the host peridotite or to the values of most parameters, with the exception of the $\mathrm{D}^{\text {sulfsil }}$ value for Re. Nevertheless this relatively simple story must be reconciled with the much more chaotic Re-Os systematics observed on a mineral scale. Since the pioneering work of Alard et al. (2002) it has been recognized that sulfides from individual peridotite samples often display a wide range of ${ }^{187} \mathrm{Os} /{ }^{188}$ Os and Re/Os compositions. Subsequent studies (e.g. Alard et al., 2005; GonzalezJimenez et al., 2013; Harvey et al., 2011, 2010) have shown that such internal heterogeneity is the rule rather than the exception in peridotites from both oceanic and continental settings. As pointed out by Alard et al. (2002) and later workers, two main types of sulfides can be defined, enclosed and interstitial, based on their petrographic setting. Enclosed sulfides, typically found as rounded inclusions in olivine, are composed of the exsolution products of monosulfide solid solution and mostly have high Os contents and low ${ }^{187} \mathrm{Os} /{ }^{188} \mathrm{Os}$ and Re/Os ratios. Interstitial sulfides are typically angular and often $\mathrm{Cu}$ and Ni-rich and are found in intergranular settings, often associated with clinopyroxene and spinel. They usually have low to very low Os concentrations, associated with high $\mathrm{Re} / \mathrm{Os}$ ratios and radiogenic Os isotope compositions. Luguet and Pearson (2019) provide a recent review of studies relating the Re-Os systematics of sulfides to their petrographic contexts. Enclosed sulfides are generally taken to be residual phases left by ancient partial melting events. In contrast, interstitial sulfides are often assumed to have been added during later metasomatic events. This perspective has led some authors to suggest that whole rock Os compositions may in fact represent the superposition of several generations of sulfides and thus may have no temporal significance (Alard et al., 2002; Harvey et al., 2011; Luguet and Pearson, 2019).

In some cases, direct addition of sulfides bearing radiogenic Os is indeed likely to be a plausible explanation of the observed internal heterogeneity. Notably, the $\sim 35 \%$ of whole rock samples that plot above ${ }^{187} \mathrm{Os} /{ }^{188} \mathrm{Os}$ vs. $\mathrm{Al}_{2} \mathrm{O}_{3}$ trends defined in each suite may have experienced addition of radiogenic Os. Many of these samples are from localities situated close to destructive plate margins, where it has been shown that radiogenic Os from the subducting slab can be mobilized and incorporated in peridotites of the mantle wedge (Brandon et al., 1996; Widom et al., 2003). Such mobility is presumably due to the existence of oxidizing and/or chlorine rich conditions in these environments, which both favor Os mobility (Wood, 1987; Xiong and Wood, 2000). Even in contexts not obviously related to subduction, such as the Montferrier locality of southern France (Alard et al., 2011), volatile rich and/or carbonatite metasomatism may add highly radiogenic sulfides. It is perhaps not surprising that most 
samples plotting above the trends are non-cratonic xenoliths (Fig. 1), since as has been long recognized (e.g. Pearson et al., 2004), the Os contents of peridotites from these tectonic settings are significantly lower than those of tectonic peridotites $(2.3 \pm 1.6 \mathrm{ppb}$ and $4.1 \pm 1.6 \mathrm{ppb}$ respectively, based on compilation in Luguet and Reisberg, 2016). The low Os contents of the non-cratonic xenoliths, which result from both post-eruptive supergene weathering (Handler and Bennett, 1999) and pre-eruptive circulation of sulfur-undersaturated melts (Ackerman et al., 2013; see Lorand and Luguet (2016) for discussion of this issue), may render the Os isotope systematics of these rocks particularly sensitive to modification.

These considerations suggest that the addition of radiogenic sulfides during a variety of metasomatic processes can explain both the internal Os isotope heterogeneity and the unexpectedly radiogenic bulk rock compositions of samples plotting above the trends in Fig. 1 and 2. It is therefore interesting to observe that samples plotting on the trends also show extensive internal Os isotope heterogeneity. This is apparent from the detailed study of Harvey et al. (2011), who performed Re/Os analyses on individual sulfides, silicate phases, spinels and their corresponding whole rocks from Kilbourne Hole in New Mexico (USA). Most of the whole rocks define a broad but undeniable correlation between ${ }^{187} \mathrm{Os} /{ }^{188} \mathrm{Os}$ and $\mathrm{Al}_{2} \mathrm{O}_{3}$ (their Figure 2). The sulfides contain nearly the entire Os budget of the rocks, with the interstitial sulfides mostly having more radiogenic and more variable Os isotope compositions as well as much lower Os concentrations than the enclosed sulfides. The authors suggest that the radiogenic interstitial sulfides were added in multiple metasomatic events, and that their contribution therefore only obscures the meaning of the whole rock Os signature.

It is understandable that metasomatic addition of sulfides could destroy preexisting correlations between Os isotope ratios and $\mathrm{Al}_{2} \mathrm{O}_{3}$ passing through the $\mathrm{PUM}$ composition. However it is difficult to imagine that this random, multifaceted process could systematically produce such trends in peridotite suites from throughout the world. Instead, where such correlations exist, the more radiogenic compositions of interstitial sulfides with high Re/Os, relative to enclosed sulfides, may simply reflect radiogenic ingrowth since the time of ancient refertilization, coupled with incomplete isotopic reequilibration with the surrounding rock. The melt percolation process described above would inevitably produce interstitial sufides almost completely bereft of Os, and thus with very high Re/Os ratios, while any enclosed residual sulfides would have high Os contents and low Re/Os ratios. Osmium isotope evolution with time in an individual sulfide would then depend not only on its Re/Os ratio, but also on the extent to which it has experienced inward and outward Os diffusion relative to the surrounding 
rock. This in turn depends on the temperature of the lithosphere relative to closure temperatures for Re and Os in the various silicate and sulfide phases. If the lithosphere remained well below the closure temperature since the time of the original melt percolation event, internal isochrons would be expected, with the interstitial sulfides reaching extremely radiogenic compositions. For example, assuming that the mantle lithosphere beneath Kilbourne Hole had an age of 1.86 $\mathrm{Ga}$, the $\mathrm{T}_{\mathrm{RD}}$ model age (assuming a mantle evolution curve passing throught the present day PUM value of 0.1296) of the least radiogenic whole rock sample from Harvey et al. (2011), the interstitial sulfides should currently have ${ }^{187} \mathrm{Os} /{ }^{188}$ Os ratios ranging from 0.28 to 2168 (Fig. 11). However this range contrasts strikingly with the range in fact observed ( 0.126 to 0.373$)$.

Similarly, though not divided into enclosed and interstitial populations, sulfides from Massif Central (France) xenoliths yielded ${ }^{187} \mathrm{Os} /{ }^{188}$ Os ratios ranging from 0.115 to 0.171 (Harvey et al., 2010), values much lower and less varied than those expected (0.12 to 25.9) from their $\mathrm{Re} / \mathrm{Os}$ ratios for $1.7 \mathrm{Ga}$ of radiogenic ingrowth (based on the oldest whole rock $\mathrm{T}_{\mathrm{RD}}$ age) in the underlying lithosphere. Thus it is clear that lithospheric temperatures were high enough to allow very substantial Os diffusion and isotopic reequilibration to occur. There is currently little direct information about Os diffusion rates in silicate rocks, but based on theoretical considerations (Kogiso et al., 2004) suggest Os diffusion coefficients in olivine of $\log \mathrm{D}=$ 16.5 to -16.4 , similar to those of $\mathrm{Sr}$ or $\mathrm{Pb}$, while the experimental study of Hayden and Watson (2007) suggests that grain boundary diffusivity of Os may be several orders of magnitude higher. This supports the possibility that the extreme Os isotope compositions expected to develop in intergranular sufides with high Re/Os ratios (Fig. 11) might be mostly erased by diffusion.
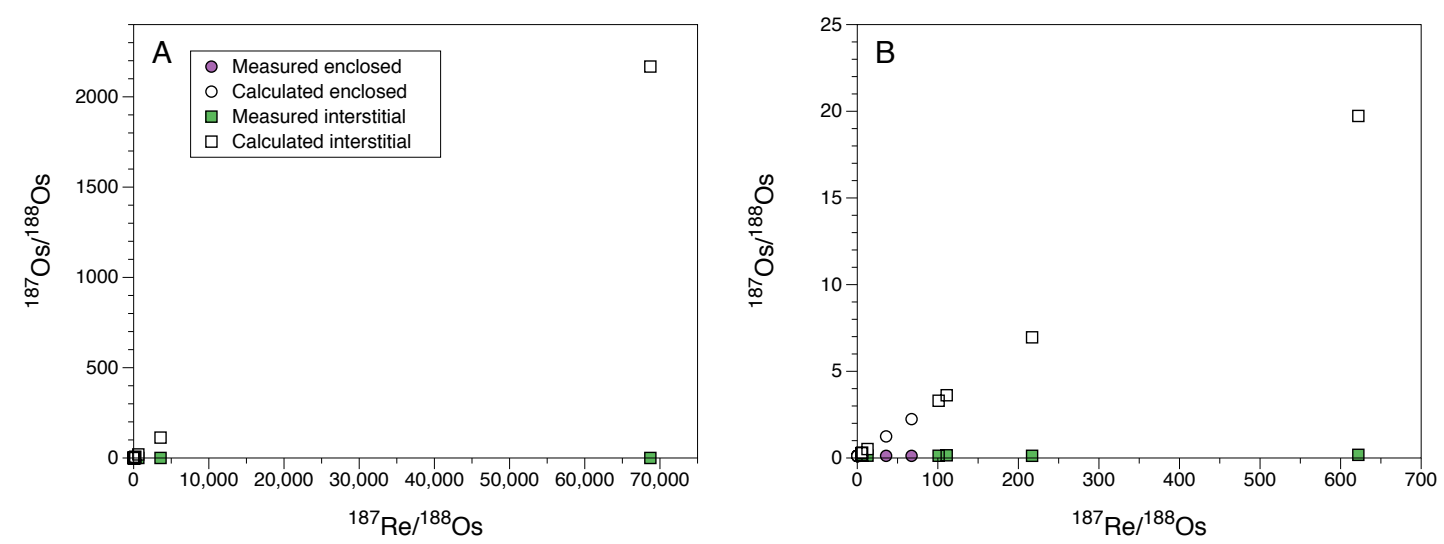

Figure 11. A) Comparison of measured ${ }^{187} \mathrm{Os} /{ }^{188} \mathrm{Os}$ ratios (filled symbols) in enclosed and interstitial sulfides from peridotite xenoliths from Kilbourne Hole with values expected after $1.86 \mathrm{Ga}$ of radiogenic ingrowth (open symbols.) Data from Harvey et al. (2011). B) Expanded view of (A). 
On the other hand, if lithospheric temperatures were well above the Re/Os closure temperature complete internal isotopic equilibrium at the hand sample scale would be expected at the time of eruption. As discussed above, this is also clearly not the case. This suggests that Re-Os diffusion rates at lithospheric temperatures were fast enough to erase most, but not all, of the expected heterogeneity between intergranular sulfides, and that enclosed sulfides were largely protected from equilibration by their Os poor silicate hosts. These conclusions are very similar to those reached by Burton et al. (1999) from their detailed analysis of spinel, silicate phases, and interstitial and included sulfides from a spinel lherzolite from Kilbourne hole. Though the nearly complete Os isotopic homogenisation they observed between the silicates and the intergranular sulfides was not confirmed by the more recent work of Harvey et al. (2011), the inference from this early study that Os diffusion is rapid enough to remove much, but not all, of the internal heterogeneity within lithospheric peridotites remains solid.

Thus Os isotopic heterogeneity among sulfides from an individual sample is not necessarily evidence for addition of radiogenic sulfides during metasomatic events unrelated to the original melt extraction episode. Instead, the somewhat chaotic but generally more radiogenic compositions of sulfides in interstitial positions are exactly what might be expected from hundreds of millions of years of radiogenic ingrowth in Re-rich sulfides coupled with extensive, but incomplete, isotopic reequilibration. There is therefore no contradiction between production of whole rock correlations between ${ }^{187} \mathrm{Os} /{ }^{188} \mathrm{Os}$ and fertility indices by radiogenic ingrowth after magma percolation immediately subsequent to melt extraction and the existence of internal Os isotope heterogeneity. This also suggests that Os model ages obtained from individual intergranular sulfide grains in non-cratonic lithospheric peridotites may have no temporal significance.

\section{Summary and broader implications}

Osmium isotopes provide a unique perspective on the transformation of harzburgite to lherzolite through melt percolation, and in particular place strong constraints on the timing of this process. Because of its extreme compatibility in the sulfide phase, essentially all of the Os carried by percolating sulfide-saturated melts will be trapped at the very bottom of the peridotite column. Therefore lherzolites formed by percolation of young, radiogenic melts through ancient harzburgites would be expected to retain the unradiogenic Os compositions of the harzburgites. The near absence of fertile lherzolites with unradiogenic Os isotope compositions thus indicates that transformation of ancient harzburgites into lherzolites by 
refertilization involving much younger magmas is a process that almost never occurs. Instead, near linear relationships, trending towards the PUM composition, between whole rock Os isotope compositions and indices of fertility are observed in most peridotite suites from the non-cratonic mantle. These correlations can be explained by ancient addition of Re-rich sulfides together with pyroxene and spinel during refertilization soon after, and likely related to, the profound melt extraction episodes that depleted the harzburgites. Radiogenic ingrowth of ${ }^{187}$ Os over time would then produce the observed correlations. Ancient refertilization would result in a lithosphere composed largely of lherzolite, which would be denser than a lithosphere dominated by harzburgite (Poudjom Djomani et al., 2001). The recognition from Os isotopes that the lherzolitic nature of the lithosphere must have been acquired early thus adds a complicating constraint that must be considered when trying to explain lithospheric stability over time.

In the modeled melt percolation process, crystallization of pyroxene and spinel triggers sulfide saturation in each step, producing correlations between Re/Os ratios and fertility indices that over time create the observed trends. The curvature of the trends produced by this model is strongly dependent on the value of $\mathrm{D}_{\mathrm{Re}}{ }^{\text {sulfsil }}$. To produce the observed linear relationships, the required $\mathrm{D}_{\mathrm{Re}}{ }^{\text {sulfsil }}$ values are in the range of about 300 to 500 , consistent with the values for $\mathrm{D}_{\mathrm{Re}}{ }^{\text {sulf } / \text { sil }}$ predicted for high $\mathrm{FeO}$ melts under the combined $f \mathrm{O}_{2}$ and $f \mathrm{~S}_{2}$ conditions expected for non-arc mantle melting (Brenan, 2008). On the other hand, most parameters other than $\mathrm{D}_{\mathrm{Re}}{ }^{\text {sulfsil }}$ have quite limited effect on the form of the ${ }^{187} \mathrm{Os} /{ }^{188} \mathrm{Os}$ vs. $\mathrm{Al}_{2} \mathrm{O}_{3}$ relationship. This lack of sensitivity to variations in most parameters, including the extent of equilibration with the preexisting harzburgite, may explain why these linear trends are so widespread. The development of such trends is not inconsistent with the extensive internal isotopic heterogeneity very commonly observed between sulfides from the same rock (Luguet and Pearson, 2019). In fact, such heterogeneity is the expected result of hundreds of millions of years of radiogenic ingrowth in sulfides with different Re/Os ratios coupled with extensive, but incomplete, diffusive reequilibration between phases in different petrographic contexts. The ${ }^{187} \mathrm{Os} /{ }^{188} \mathrm{Os}$ ratios of individual sulfides thus are unlikely to have time significance and probably cannot be associated with specific tectonic events.

Finally, it is interesting to speculate on the geodynamic context likely to produce the observed relationships between ${ }^{187} \mathrm{Os} /{ }^{188}$ Os and fertility indices. Most authors think that the continental crust was formed in arc environments (see Arndt (2013) for a review), but peridotite xenoliths from these settings often have highly radiogenic and unsystematic Os isotope compositions 
(Brandon et al., 1996; Widom et al., 2003). Furthermore, percolation modeling using the low

$\mathrm{D}_{\mathrm{Re}}{ }^{\text {sulf } / \text { sil }}$ values appropriate for oxidizing suprasubduction conditions produces highly curved trends plotting far from the data. Hence it seems likely that the subcontinental non-cratonic lithosphere was not formed in arc settings. Instead, profound harzburgite-forming partial melting episodes followed shortly afterwards by percolation of the remaining melts through the cooling lithosphere are likely to occur above large mantle plumes. In this context, it is interesting that the Os isotope data suggest that nearly all of the non-cratonic lithosphere is of Paleo to mid Proterozoic age. Arndt and Davaille (2013) suggest that the distinctive peaks in the $\mathrm{U}-\mathrm{Pb}$ zircon age record from that time period can be explained by the periodic generation of massive mantle plumes. Such plumes would not only produce intense melting events in the upper mantle, but would also accelerate plate tectonics leading to pulses of increased granite production. Thus it is possible that Proterozoic mantle lithosphere formed above mantle plumes and was then tectonically juxtaposed with nearby continental crust of similar age to produce the non-cratonic lithosphere observed today. In any case, the nearly ubiquitous linear relationships between Os isotopes and fertility indices place strong constraints on models of formation of the non-cratonic lithosphere underlying most of the Earth's continental area.

\section{Acknowledgements}

I thank the editor, Catherine Chauvel, for inviting this review paper. Lyderic France, Juliette Pin, and all the members of the Magma discussion group at CRPG are thanked for their insightful questions and comments. The constructive suggestions of the reviewers, James Brenan and Igor Puchtel, are greatly appreciated.

\section{References}

Ackerman, L., Pitcher, L., Strnad, L., Puchtel, I.S., Jelínek, E., Walker, R.J., Rohovec, J., 2013. Highly siderophile element geochemistry of peridotites and pyroxenites from Horní Bory, Bohemian Massif: Implications for HSE behaviour in subduction-related upper mantle. Geochimica et Cosmochimica Acta 100, 158-175. https://doi.org/10.1016/j.gca.2012.09.050

Alard, O., Griffin, W.L., Pearson, N., Lorand, J.P., O’Reilly, S.Y., 2002. New insights into the Re-Os systematics of subcontinental lithospheric mantle from in-situ analyses of sulfides. Earth Planet. Sci. Lett. 203, 651-663.

Alard, O., Lorand, J.-P., Reisberg, L., Bodinier, J.-L., Dautria, J.-M., O’Reilly, S.Y., 2011. Volatile-rich Metasomatism in Montferrier Xenoliths (Southern France): Implications for the Abundances of Chalcophile and Highly Siderophile Elements in the Subcontinental Mantle. J Petrology 52, 2009-2045. https://doi.org/10.1093/petrology/egr038

Alard, O., Luguet, A., Pearson, N.J., Griffin, W.L., Lorand, J.-P., Gannoun, A., Burton, K.W., O’Reilley, S.Y., 2005. In situ Os isotopes in abyssal peridotites bridge the isotopic gap between MORBs and their source mantle. Nature 436, 1005-1008.

Armytage, R.M.G., Brandon, A.D., Peslier, A.H., Lapen, T.J., 2014. Osmium isotope evidence for Early to Middle Proterozoic mantle lithosphere stabilization and concomitant production of juvenile crust in Dish Hill, CA peridotite xenoliths. Geochimica et Cosmochimica Acta 137, 113-133. https://doi.org/10.1016/j.gca.2014.04.017 
Arndt, N., 2013. Formation and Evolution of the Continental Crust. GeochemPersp 2, 405-533. https://doi.org/10.7185/geochempersp.2.3

Arndt, N., Davaille, A., 2013. Episodic Earth evolution. Tectonophysics, Moho: 100 years after Andrija Mohorovicic 609, 661-674. https://doi.org/10.1016/j.tecto.2013.07.002

Becker, H., Dale, C.W., 2016. Re-Pt-Os Isotopic and Highly Siderophile Element Behavior in Oceanic and Continental Mantle Tectonites. Reviews in Mineralogy and Geochemistry 81, 369-440. https://doi.org/10.2138/rmg.2016.81.7

Bodinier, J.-L., Godard, M., 2014. Orogenic, Ophiolitic, and Abyssal Peridotites, in: The Mantle and Core, Treatise on Geochemistry - 2nd Edition. Elsevier, pp. 103-167.

Brandon, A.D., Creaser, R.A., Shirey, S.B., Carlson, R.W., 1996. Osmium recycling in subduction zones. Science 272, $861-864$.

Brenan, J.M., 2008. Re-Os fractionation by sulfide melt-silicate melt partitioning: A new spin. Chemical Geology, Highly Siderophile Element Geochemistry 248, 140-165. https://doi.org/10.1016/j.chemgeo.2007.09.003

Brenan, J.M., Bennett, N.R., Zajacz, Z., 2016. Experimental Results on Fractionation of the Highly Siderophile Elements (HSE) at Variable Pressures and Temperatures during Planetary and Magmatic Differentiation. Reviews in Mineralogy and Geochemistry 81, 1-87. https://doi.org/10.2138/rmg.2016.81.1

Burnham, O.M., Rogers, N.W., Pearson, D.G., van Calsteren, P.W., Hawkesworth, C.J., 1998. The petrogenesis of the eastern Pyrenean peridotites: an integrated study of their whole-rock geochemistry and Re-Os isotope composition. Geochimica et Cosmochimica Acta 62, 2293-2310. https://doi.org/10.1016/S0016-7037(98)00092-1

Burton, K.W., Gannoun, A., Birck, J.-L., Allègre, C.J., Schiano, P., Clocchiatti, R., Alard, O., 2002. The compatibility of rhenium and osmium in natural olivine and their behaviour during mantle melting and basalt genesis. Earth Planet. Sci. Lett. 198, 63-76.

Burton, K.W., Schiano, P., Birck, J.-L., Allègre, C.J., 1999. Osmium isotope disequilibrium between mantle minerals in a spinel-lherzolite. Earth Planet. Sci. Lett. 172, 311-322.

Byerly, B.L., Lassiter, J.C., 2012. Evidence from mantle xenoliths for lithosphere removal beneath the central Rio Grande Rift. Earth and Planetary Science Letters 355-356, 82-93. https://doi.org/10.1016/j.eps1.2012.08.034

Fonseca, R.O.C., Mallmann, G., O’Neill, H.S.C., Campbell, I.H., 2007. How chalcophile is rhenium? An experimental study of the solubility of Re in sulphide mattes. Earth Planet. Sci. Lett. 260, 537-548.

Frey, F.A., Prinz, M., 1978. Ultramafic inclusions from San Carlos, Arizona: petrologic and geochemical data bearing on their petrogenesis. Earth Planet. Sci. Lett. 38, 129-176.

Gannoun, A., Burton, K.W., Day, J.M.D., Harvey, J., Schiano, P., Parkinson, I., 2016. Highly Siderophile Element and Os Isotope Systematics of Volcanic Rocks at Divergent and Convergent Plate Boundaries and in Intraplate Settings. Reviews in Mineralogy and Geochemistry 81, 651-724. https://doi.org/10.2138/rmg.2016.81.11

Gao, S., Rudnick, R., Carlson, R.W., McDonough, W.F., Liu, Y.-S., 2002. Re-Os evidence for replacement of ancient mantle lithosphere beneath the North China craton. Earth Planet. Sci. Lett. 198, 307-322.

Gonzalez-Jimenez, J.M., Villaseca, C., Griffin, W.L., Belousova, E., Konc, Z., Ancochea, E., O’Reilly, S.Y., Pearson, N.J., Garrido, C.J., Gervilla, F., 2013. The architecture of the European-Mediterranean lithosphere: A synthesis of the Re-Os evidence. Geology 41, 547-550. https://doi.org/10.1130/G34003.1

Handler, M.R., Bennett, V., 1999. Behaviour of platinum-group elements in the subcontinental mantle of eastern Australia during variable metasomatism and melt depletion. Geochim. Cosmochim. Acta 63, 3597-3618.

Handler, M.R., Wysoczanski, R.J., Gamble, J.A., 2003. Proterozoic lithosphere in Marie Byrd Land, West Antarctica: Re-Os systematics of spinel peridotite xenoliths. Chemical Geology, Highly Siderophile elements in the Earth and Meteorties: A volume in honor of john Morgan 196, 131-145. https://doi.org/10.1016/S0009-2541(02)00410-2

Harvey, J., Dale, C.W., Gannoun, A., Burton, K.W., 2011. Osmium mass balance in peridotite and the effects of mantlederived sulphides on basalt petrogenesis. Geochim. Cosmochim. Acta 75, 5574-5596. https://doi.org/10.1016/j.gca.2011.07.001

Harvey, J., Gannoun, A., Burton, K.W., Schiano, P., Rogers, N.W., Alard, O., 2010. Unravelling the effects of melt depletion and secondary infiltration on mantle Re-Os isotopes beneath the French Massif Central. Geochimica et Cosmochimica Acta 74, 293-320. https://doi.org/10.1016/j.gca.2009.09.031

Hayden, L.A., Watson, E.B., 2007. A diffusion mechanism for core-mantle interaction. Nature 450, 709-711. https://doi.org/10.1038/nature 06380 
Ionov, D.A., Ashchepkov, I.V., Stosch, H.-G., Witt-Eickschen, G., Seck, H.A., 1993. Garnet Peridotite Xenoliths from the Vitim Volcanic Field, Baikal Region: the Nature of the Garnet--Spinel Peridotite Transition Zone in the Continental Mantle. Journal of Petrology 34, 1141-1175. https://doi.org/10.1093/petrology/34.6.1141

Jaques, A.L., Green, D.H., 1980. Anhydrous melting of peridotite at $0-15 \mathrm{~Kb}$ pressure and the genesis of tholeiitic basalts. Contr. Mineral. and Petrol. 73, 287-310. https://doi.org/10.1007/BF00381447

Kogiso, T., Hirschmann, M.M., Reiners, P.W., 2004. Length scales of mantle heterogeneities and their relationship to ocean island basalt geochemistry. Geochimica et Cosmochimica Acta 68, 345-360. https://doi.org/10.1016/S00167037(03)00419-8

Le Roux, V., Bodinier, J.-L., Tommasi, A., Alard, O., Dautria, J.-M., Vauchez, A., Riches, A.J.V., 2007. The Lherz spinel lherzolite: Refertilized rather than pristine mantle. Earth Planet. Sci. Lett. 259, 599-612. https://doi.org/10.1016/j.eps1.2007.05.026

Le Roux, V., Nielsen, S.G., Sun, C., Yao, L., 2016. Dating layered websterite formation in the lithospheric mantle. Earth and Planetary Science Letters 454, 103-112. https://doi.org/10.1016/j.eps1.2016.08.036

Li, C., Ripley, E.M., 2005. Empirical equations to predict the sulfur content of mafic magmas at sulfide saturation and applications to magmatic sulfide deposits. Miner Deposita 40, 218-230. https://doi.org/10.1007/s00126-005-0478-8

Lorand, J.-P., Luguet, A., 2016. Chalcophile and Siderophile Elements in Mantle Rocks: Trace Elements Controlled By Trace Minerals. Reviews in Mineralogy and Geochemistry 81, 441-488. https://doi.org/10.2138/rmg.2016.81.08

Luguet, A., Pearson, G., 2019. Dating mantle peridotites using Re-Os isotopes: The complex message from whole rocks, base metal sulfides, and platinum group minerals. American Mineralogist 104, 165-189. https://doi.org/10.2138/am2019-6557

Luguet, A., Reisberg, L., 2016. Highly Siderophile Element and 187Os Signatures in Non-cratonic Basalt-hosted Peridotite Xenoliths: Unravelling the Origin and Evolution of the Post-Archean Lithospheric Mantle. Reviews in Mineralogy and Geochemistry 81, 305-367. https://doi.org/10.2138/rmg.2016.81.06

Luguet, A., Shirey, S.B., Lorand, J.-P., Horan, M.F., Carlson, R.W., 2007. Residual platinum-group minerals from highly depleted harzburgites of the Lherz massif (France) and their role in HSE fractionation of the mantle. Geochimica et Cosmochimica Acta 71, 3082-3097. https://doi.org/10.1016/j.gca.2007.04.011

Mallmann, G., O’Neill, H.S.C., 2007. The effect of oxygen fugacity on the partitioning of Re between crystals and silicate melt during mantle melting. Geochim. Cosmochim. Acta 71, 2837-2857.

McKenzie, D., O’nions, R.K., 1991. Partial Melt Distributions from Inversion of Rare Earth Element Concentrations. J Petrology 32, 1021-1091. https://doi.org/10.1093/petrology/32.5.1021

Meisel, T., Walker, R.J., Irving, A.J., Lorand, J.-P., 2001. Osmium isotopic compositions of mantle xenoliths: a global perspective. Geochim. Cosmochim. Acta. 65, 1311-1323.

Mungall, J.E., Brenan, J.M., 2014. Partitioning of platinum-group elements and Au between sulfide liquid and basalt and the origins of mantle-crust fractionation of the chalcophile elements. Geochimica et Cosmochimica Acta 125, 265-289. https://doi.org/10.1016/j.gca.2013.10.002

Navon, O., Stolper, E., 1987. Geochemical consequences of melt percolation: The upper mantle as a chromatographic column. J. Geology 95, 285-307.

Pearson, D.G., Irvine, G.J., Ionov, D.A., Boyd, F.R., Dreibus, G.E., 2004. Re-Os isotope systematics and platinum group element fractionation during mantle melt extraction: a study of massif and xenolith peridotite suites. Chem. Geol. 208, $29-59$.

Peslier, A.H., Reisberg, L., Ludden, J., Francis, D., 2000. Re-Os constraints on harzburgite and lherzolite formation in the lithospheric mantle: A study of Northern Canadian Cordillera xenoliths. Geochim. Cosmochim. Acta 64, 3061-3071.

Peucker-Ehrenbrink, B., Jahn, B.-M., 2001. Rhenium-osmium isotope systematics and platinum group element concentrations: Loess and the upper continental crust. G-cubed 2, paper number $2001 \mathrm{GC} 000172$.

Poudjom Djomani, Y.H., O’Reilly, S.Y., Griffin, W.L., Morgan, P., 2001. The density structure of subcontinental lithosphere through time. Earth Planet. Sci. Lett. 184, 605-621.

Puchtel, I.S., Humayun, M., Campbell, A.J., Sproule, R.A., Lesher, C.M., 2004. Platinum group element geochemistry of komatiites from the Alexo and Pyke Hill areas, Ontario, Canada 11Associate editor: R. J. Walker. Geochimica et Cosmochimica Acta 68, 1361-1383. https://doi.org/10.1016/j.gca.2003.09.013

Reisberg, L., Lorand, J.-P., 1995. Longevity of sub-continental mantle lithosphere from osmium isotope systematics in 
orogenic peridotite massifs. Nature 376, 159-162.

Reisberg, L., Zhi, X., Lorand, J.-P., Wagner, C., Peng, Z., Zimmermann, C., 2005. Re-Os and S systematics of spinel peridotite xenoliths from east central China: Evidence for contrasting effects of melt percolation. Earth Planet. Sci. Lett. 239, 286-308.

Roy Barman, M., Wasserburg, G.J., Papanastassiou, D.A., Chaussidon, M., 1998. Osmium isotopic compositions and ReOs concentrations in sulfide globules from basaltic glasses. Earth Planet. Sci. Lett. 154, 331-347.

Sattari, P., Brenan, J.M., Horn, I., McDonough, W.F., 2002. Experimental Constraints on the Sulfide- and ChromiteSilicate Melt Partitioning Behavior of Rhenium and Platinum-Group Elements. Economic Geology 97, $385-398$. https://doi.org/10.2113/gsecongeo.97.2.385

Smoliar, M.I., Walker, R.J., Morgan, J.W., 1996. Re-Os ages of Group IIA, IIIA, IVA, and IVB iron meteorites. Science 271, 1099-1102.

Vernières, J., Godard, M., Bodinier, J.-L., 1997. A plate model for the simulation of trace element fractionation during partial melting and magma transport in the Earth's upper mantle. J. Geophys. Res. 102, 24,771-24,784.

Walker, R., Carlson, R., Shirey, S., Boyd, F., 1989. Os, Sr, Nd, and Pb Isotope Systematics of Southern African Peridotite Xenoliths - Implications for the Chemical Evolution of Subcontinental Mantle. Geochim. Cosmochim. Acta 53, 15831595. https://doi.org/10.1016/0016-7037(89)90240-8

Widom, E., Kepezhinskas, P., Defant, M., 2003. The nature of metasomatism in the sub-arc mantle wedge: evidence from Re-Os isotopes in Kamchatka peridotite xenoliths. Chem. Geol. 196, 283+306.

Wood, B.J., Kiseeva, E.S., Matzen, A.K., 2013. Garnet in the Earth’s Mantle. Elements 9, 421-426. https://doi.org/10.2113/gselements.9.6.421

Wood, S.A., 1987. Thermodynamic calculations of the volatility of the platinum group elements (PGE): The PGE content of fluids at magmatic temperatures. Geochim. Cosmochim. Acta 51, 3041-3050.

Wu, F.-Y., Walker, R.J., Yang, Y.-H., Yuan, H.-L., Yang, J.-H., 2006. The chemical-temporal evolution of lithospheric mantle underlying the North China Craton. Geochim. Cosmochim. Acta 70, 5013-5034.

Xiong, Y., Wood, S.A., 2000. Experimental quantification of hydrothermal solubility of platinum-group elements with special reference to porphyry copper environments. Mineralogy and Petrology 68, 1-28. https://doi.org/10.1007/s007100050001

Zindler, A., Hart, S.R., 1986. Chemical geodynamics. Ann. Rev. Earth Planet. Sci. 14, 493-571. 